\title{
Rancang Bangun Aplikasi Sistem Pakar Diagnosis Gangguan Emosional Pada Anak Berbasis Aplikasi Website
}

\author{
Fanidia Nur Utami, Kodrat Iman Satoto, Kurniawan Teguh Martono \\ Program Studi Sistem Komputer Fakultas Teknik Universitas Diponegoro \\ Jalan Prof. Sudharto, Tembalang, Semarang, Indonesia \\ fanidianu@outlook.com
}

\begin{abstract}
Abstrak - Ketepatan diagnosis terhadap suatu penyakit dan kecepatan proses penentuan diagnosis sangat penting dalam dunia kesehatan. Proses diagnosis penyakit ditentukan dari pengetahuan tenaga medis yang menangani pasien. Kesalahan diagnosis penyakit dan keterlambatan menentukan solusi pengobatan dapat memberikan dampak buruk bagi kesehatan pasien. Namun, tenaga medis yang dapat melayani terkadang jumlahnya terbatas. Penelitian ini dikhususkan untuk merancang suatu aplikasi sistem pakar diagnosis gangguan emosional yang disesuaikan dengan Pedoman Panduan Diagnosis Gangguan Jiwa di Indonesia.

Perancangan sistem pakar pada penelitian ini bertujuan untuk menerapkan ilmu kecerdasan buatan, metodologi waterfall dan aplikasi website. Perencanaan sistem menggunakan metode terstruktur dengan mendefinisikan DFD, ERD, serta diagram alir sistem. Sistem pakar dirancang berbasis aplikasi website sehingga program ditulis dengan bahasa pemrograman C\# dan Razor untuk bagian view sedangkan basisdata program menggunakan SQL Server Local Database

Proses diagnosis penyakit pada penelitian ini menggunakan metode forward chaining. Pengujian aplikasi sistem pakar ini menggunakan metode pengujian white box. Berdasarkan hasil pengujian white box, tidak ditemukan kesalahan fungsi dan proses diagnosis pada aplikasi.
\end{abstract}

Kata Kunci : gangguan emosional, aplikasi website, sistem pakar, forward chaining, pengujian WhiteBox

\section{Pendahuluan}

$P$ ADA saat ini terjadi perkembangan yang pesat dalam bidang ilmu pengetahuan dan teknologi, khususnya teknologi komputer dan komunikasi atau sering disebut dengan era Information and Communication Technology (ICT). Jika pada mulanya komputer digunakan hanya sekedar alat penghitung, maka saat ini komputer telah mampu menggantikan peran atau tugas-tugas rumit yang dilakukan oleh manusia, bahkan sanggup menirukan proses biologis manusia dalam pengambilan keputusan yang disebut kecerdasan buatan.

Perkembangan teknologi yang menghasilkan produk dengan mengimplementasikan ilmu kecerdasan buatan dapat melalui pengembangan sebuah aplikasi untuk dapat menghasilkan suatu keputusan. Salah satunya adalah penggunaan konsep sistem pakar. Sistem ini dirancang untuk menirukan keahlian seorang pakar dalam menjawab pertanyaan dan menyelesaikan suatu permasalahan baik di bidang kesehatan atau kedokteran, bisnis, ekonomi dan sebagainya.

Pengimplementasian sistem pakar pada dunia kedokteran atau kesehatan dapat berupa diagnosis penyakit, konsultasi penjagaan kesehatan hingga pemberian saran penentuan solusi dari hasil diagnosis yang ada dengan cepat dan tepat. Rancang bangun sistem pakar diagnosis gangguan emosional pada anak ini memiliki tujuan untuk merancang suatu aplikasi yang dapat melakukan diagnosis gangguan emosional pada anak dengan menerapkan salah satu teknik kecerdasan buatan yaitu teknik reasoning denga menggunakan runut maju (forward chaining) dan teknik representasi pengetahuan berupa kaidah produksi.

Dalam pembuatan tugas akhir ini pembahasan masalah memiliki batasan pada permasalahan berikut :

a. Aplikasi sistem pakar diagnosis Gangguan emosi (emotional disorder) dirancang dan dibuat berbasis aplikasi website dengan menggunakan framework ASP.NET MVC bahasa pemrograman C\#.

b. Fitur aplikasi sistem pakar diagnosis Gangguan emosional (emotional disorder) pada anak meliputi keterangan gejalagejala, diagnosis dan cara penanganan dari gangguan emosional tersebut.

c. Fitur tambahan yang ditawarkan dalam aplikasi sistem pakar diagnosis gangguan emosional (emotional disorder) pada anak berbasis website adalah tanya pakar.

d. Aplikasi hanya dapat menyimpan 10 jenis gangguan emosional dan gejala sebanyak 40 buah.

e. Implementasi aplikasi sistem pakar diagnosis gangguan emosional pada anak adalah sebatas hanya pada host lokal dan menggunakan basisdata sql server lokal.

f. Lingkup kelainan psikologi hanya meliputi gangguan emosional (emotional disorder) pada anak maupun remaja yang terbagi menjadi dua, yaitu: mood disorders (gangguan suasana hati) dan anxiety disorders (gangguan kegelisahan) mengacu pada referensi buku PPDGJ-III dan berdasarkan pengetahuan dari seorang pakar (psikiater dan psikolog).

\section{A. Penelitian Terdahulu}

\section{LANDASAN TEORI}

Dalam melakukan penelitian mengenai rancang bangun aplikasi sistem pakar diagnosis gangguan emosional berbasis 
website mengambil beberapa referensi dari jurnal terkait sistem pakar dan psikologis anak. Pada penelitian sebelumnya, beberapa point yang dapat disimpulkan diantaranya :

Pada jurnal "Rancang Bangun Aplikasi Sistem Pakar Untuk Menentukan Jenis Gangguan Perkembangan Pada Anak", sistem sudah mampu menganalisis jenis gangguan perkembangan yang dialalmi pasien berdasarkan gejala-gejala yang dimasukkan oleh user. Aplikasi mampu menyimpan representasi pengetahuan pakar berdasarkan nilai kebenaran MB dan nilai ketidakbenaran MD. Aplikasi sistem pakar ini sudah dapat menjelaskan definisi jenis gangguan perkembangan, penyebab dan pengobatannya. ${ }^{[1]}$

Perbedaannya dengan penelitian yang akan dilakukan oleh penulis adalah aplikasi yang dibangun berupa aplikasi website yang dibuat menggunakan ASP.NET MVC dan bahasa

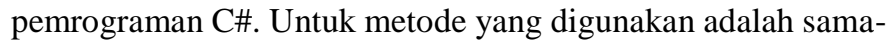
sama runut maju, hanya saja pada penelitian kali ini penulis tidak memperitungkan nilai kebenaran dan nilai ketidakbenaran. Teknik representasi yang dipilih dalam penelitian ini adalah kaidah produksi.

\section{B. Kecerdasan Buatan}

Kecerdasan buatan (artificial intelligence) merupakan salah satu bagian dari ilmu komputer yang mempelajari bagaimana membuat mesin (komputer) dapat melakukan pekerjaan seperti dan sebaik yang dilakukan oleh manusia bahkan lebih baik daripada yang dilakukan manusia. ${ }^{[2]}$

\section{Sistem Pakar}

Sistem pakar merupakan sebuah sistem yang menggunakan pengetahuan manusia di mana pengetahuan tersebut dimasukkan ke dalam sebuah komputer dan kemudian digunakan untuk menyelesaikan masalah-masalah yang biasanya membutuhkan kepakaran atau keahlian manusia.

Sistem pakar dikembangkan dalam berbagai bidang termasuk dalam bidang medis. Saat ini kebutuhan manusia akan pelayanan medis yang lebih baik sangat mendesak, yang berarti dukungan instrumentasi dan informatika medis modern (telemedis) menjadi sangat dibutuhkan termasuk metode untuk membantu analisisnya sehingga dihasilkan diagnosis yang lebih optimal. ${ }^{[3]}$

Sistem pakar memiliki ciri-ciri sebagai berikut:

1. Terbatas pada domain keahlian tertentu.

2. Dapat memberikan penalaran untuk data-data yang tidak pasti.

3. Dapat menyesuaikan rangkaian alasan-alasan yang diberikannya dengan cara yang dapat dipahami.

4. Dirancang untuk dapat dikembangkan secara bertahap.

5. Keluarannya bersifat anjuran

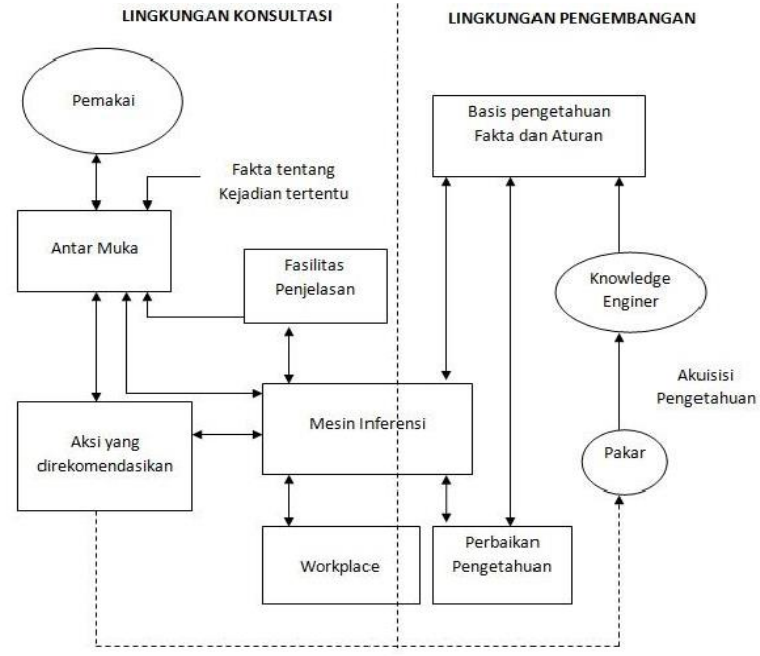

Gambar 1. Arsitektur Sistem Pakar ${ }^{[4]}$

Beberapa istilah yang terdapat dalam sistem pakar diantaranya: mesin inferensi dan teknik representasi pengetahuan. Mesin inferensi merupakan program computer yang memberikan metodologi untuk penalaran tentang informasi yang ada dalam basis pengetahuan dan dalam workplace, dan untuk memformulasikan kesimpulan. Ada 2 (dua) metode inferensi yang umum dalam sistem pakar yaitu:

1. Forward Chaining (Runut Maju)

Forward chaining adalah pendekatan yang dimotori data (data-driven). Dalam pendekatan ini, pelacakan dimulai dari informasi masukan dan selanjutnya mencoba menggambarkan kesimpulan. Forward chaining mencari fakta yang sesuai dengan bagian IF dari aturan IF-THEN. ${ }^{[5]}$

Kelebihan forward chaining adalah data baru dapat dimasukkan ke dalam basisdata inferensi yang membuat sistem menjadi lebih dinamis karena mengikuti perubahan fakta yang mendukung kesimpulan.

\section{Backward Chaining (Runut Mundur)}

Backward chaining adalah pendekatan yang dimotori tujuan (goal driven). Dalam pendekatan ini pelacakan dimulai dari tujuan, selanjutnya dicari aturan yang memiliki tujuan tersebut untuk kesimpulannya. Lalu, proses pelacakan menggunakan premis aturan tersebut sebagai tujuan baru dan mencari aturan lain dengan tujuan baru sebagai kesimpulannya. ${ }^{[5]}$

Teknik representasi pengetahuan merupakan suatu teknik untuk merepresentasikan basis pengetahuan yang diperoleh ke dalam suatu diagram tertentu sehingga dapat diketahui relasi/keterhubungan antar suatu data dengan data yang lain. Salah satu teknik yang digunakan dalam penelitian ini adalah kaidah produksi, yaitu dengan merepresentasikan pengetahuan dalam bentuk IF-THEN menghubungkan antesenden (antecedent) dengan konsekuensi yang diakibatkannya.

Dalam model representasi pengetahuan kaidah produksi, terdapat beberapa tahapan yang harus ditempuh dari pengetahuan yang didapatkan dalam domain tertentu. Langkahlangkah tersebut adalah menyajikan pengetahuan yang berhasil didapatkan dalam bentuk table keputusan (decision table) kemudian dari table keputusan dibuat pohon keputusan (tree decision) ${ }^{[5]}$ 


\section{Microsoft Visual Studio}

Microsoft visual studio merupakan sebuah perangkat lunak lengkap yang dapat digunakan untuk melakukan pengembangan aplikasi, baik itu aplikasi bisnis, aplikasi personal ataupun komponen aplikasinya, dalam bentuk aplikasi console, aplikasi windows ataupun aplikasi website. Dalam penelitian ini Microsoft Visual Studio yang digunakan adalah Microsoft Visual Studia Express for Web ${ }^{[6]}$.

\section{E. ASP.NET MVC}

ASP.NET MVC merupakan suatu framework untuk pengembangan website pada platform Microsoft .NET yang menyediakan jalan bagi para pengembang untuk membangun aplikasi website dengan struktur yang baik ${ }^{[7]}$ ASP.NET MVC secara signifikan telah berkembang dan popular sejak pertama kali dipublikasikan yaitu pada tahun 2007. MVC merupakan kependekan dari model-view-controller ${ }^{[8]}$.

\section{F. Entity Framework}

Entity framework merupakan sekumpulan teknologi ADO.NET yang membantu memetakan antara pengembangan object-oriented dan basis data ${ }^{[9]}$. Terdapat tiga cara untuk bekerja dengan entity framework, diantaranya adalah: Database First, Model First dan Code First.

\section{G. SQL Server Database}

SQL Server merupakan sebuah host dari runtime .NET . Beberapa versi sebelum CLR 2.0 sudah ada untuk menjalankan aplikasi .NET, misalnya host untuk ASP.NET. Setiap basis data yang menggunakan kode CLR menciptakan domain aplikasi sendiri. Hal ini menjamin bahwa CLR kode dari satu database tidak memiliki inflence pada database lain. Faktor yang paling penting dalam melakukan pemrograman SQL Server adalah tingkat keamanan yang memiliki level tinggi ${ }^{[11]}$

\section{H. Bahasa Pemrograman C\#}

Bahasa pemrograman C\# dirancang oleh Microsoft Corp. sebagai bahasa pemrograman yang berdaya-guna, aman serta mudah digunakan. Sebagai bagian dari platform .NET, bahasa pemrograman $\mathrm{C \#}$ dirancang untuk bekerja dengan baik diatas framework .NET, yang mampu digunakan untuk menulis perangkat lunak yang handal demi layanan yang cepat[ ${ }^{11]}$. Bahasa pemrograman $\mathrm{C} \#$ juga dapat digunakan untuk mengembangkan aplikasi-aplikasi sarana bergerak (mobile application), aplikasi berbasis website (Web-based application) serta aplikasi berskala besar (Enterprise ${ }^{[12]}$

\section{Razor}

Razor merupakan salah satu dari view engine yang menggunakan pendekatan dengan focus pada template code ${ }^{[13]}$ Razor memungkinkan pengguna untuk memulai dengan tag HTML statis (atau konten teks) dan kemudian membuatnya dinamis dengan menambahkan kode server didalamnya. Salah satu tujuan inti di balik Razor adalah untuk membuat proses coding menjadi mudah, dan dapat memungkinkan anda dengan cepat mengintegrasikan kode server ke markup HTML dengan meminimalkan penekanan tombol pada keyboard.

\section{J. Model Pengembangan Perangkat Lunak Waterfall}

Pengembangan perangkat lunak merupakan sebuah pembelajaran iteratif atau berulang dan produk yang dihasilkan merupakan perwujudan dari pengetahuan yang dikumpulkan, disaring dan ditata selama proses berlangsung. Indikator keberhasilan perangkat lunak adalah kualitas, ketepatan waktu dan keberlangsungan jangka panjang dari sebuah produk perangkat lunak yang dihasilkan. Salah satu model pengembangang perangkat lunak adalah model waterfall. ${ }^{[14]}$

Waterfall atau air terjun adalah model yang dikembangkan untuk pengembangan perangkat lunak, membuat perangkat lunak. model berkembang secara sistematis dari satu tahap ke tahap lain dalam mode seperti air terjun. Model ini mengusulkan sebuah pendekatan kepada pengembangan software yang sistematik dan sekuensial yang mulai dari tingkat kemajuan sistem pada seluruh analisis, desain, kode, pengujian dan pemeliharaan. Model ini melingkupi aktivitas-aktivitas sebgai berikut : rekayasa dan pemodelan sistem informasi, analisis kebutuhan, desain, penulisan kode program, mengujian dan pemeliharaan. Model pengembangan ini bersifat linear dari tahap awal pengembangan system yaitu tahap perencanaan sampai tahap akhir pengembangan system yaitu tahap pemeliharaan. Tahapan berikutnya tidak akan dilaksanakan sebelum tahapan sebelumnya selesai dilaksanakan dan tidak bisa kembali atau mengulang ke tahap sebelumnya.

\section{K. Psikologi Abnormal Anak}

Studi mengenai perilaku abnormal sering membuat seseorang lebih sensitif dan waspada terhadap cara yang digunakan untuk menggambarkan perilaku orang lain. Gangguan psikologis didefinisikan sebagai pola perilaku, kognitif, emosional, atau gejala fisik yang ditunjukkan oleh seorang individu. ${ }^{[15]}$

Pengelompokkan gangguan emosional terbagi menjadi dua kelompok yaitu gangguan rasa cemas (anxiety disorder) dan gangguan suasana hati (mood disorder). Anak-anak yang mengalami rasa cemas yang berlebihan ataupun justru tidak memiliki rasa gelisah dapat dikatakan mengalami gangguan rasa cemas (anxiety disorder). ${ }^{[16]}$

Gangguan suasana hati adalah suatu kondisi dimana seorang anak atau seorang remaja yang secara konstan dapat menjadi sangat tidak senang, menunjukkan sedikit rasa antusia, suasana hati yang berubah sangat cepat atau bahkan menjadi sangat buruk dan memiliki pemirikan bahwa kehidupan bukan hanya bernilai sekedar kehidupan. Anak-anak yang mengalami mood disorders (gangguan suasana hati) menderita kondisi emosionalnya yang dapat berubah secara tiba-tiba dari kondisi emosi yang buruk, stabil hingga dalam keadaan paling ekstrem. Contohnya kondisi perasaan yang tidak senang secara berlebihan atau suasana hati dapat dengan mudah berubah dari kesedihan yang dalam ke kegembiraan yang tinggi 


\section{PERANCANGAN Sistem \\ A. Identifikasi Kebutuhan Sistem Pakar}

Tahapan yang terlebih dahulu harus dilakukan dalam melakukan rancang bangun aplikasi sistem pakar diagnosis gangguan emosional pada anak adalah menentukan tiap-tiap kebutuhan yang menjadi inti dari pembuatan sistem pakar. Pada tahapan ini, knowledge engineer berusaha untuk menyerap pengetahuan yang selanjutnya akan ditransfer ke dalam pengetahuan. Beberapa identifikasi kebutuhan dalam hal pengetahuan sistem untuk membangun sistem pakar diantaranya adalah: sumber informasi, identifikasi masalah, akuisisi pengetahuan, konseptualisasi, identifikasi masukkan (input) dan identifikasi keluaran (output).

Informasi yang dibutuhkan dalam penelitian ini adalah informasi mengenai gejala, bagaimana cara melakukan diagnosis, diagnosis apa yang tepat dan bagaimana cara penanganannya harus diperoleh dari seorang pakar langsung. Pakar yang terlibat dalam rancang bangun aplikasi ini adalah seorang psikiater maupun seorang psikolog yang bekerja di RSJ maupun membuka klinik konsultasi. Selain berasal dari seorang pakar langsung, beberapa informasi mengenai gejala, diagnosis dan penangan gangguan emosional pada anak juga diperoleh dari buku maupun artikel mengenai gangguan emosional pada umumnya meliputi gangguan kecemasan (anxiety disorder) dan gangguan suasana hati (mood disorder).

Akuisisi pengetahuan merupakan tahapan akumulasi, transfer dan transformasi keahlian dalam menyelesaikan masalah dari sumber pengetahuan ke dalam program komputer. Dengan kata lain, pada tahapan ini penulis melakukan perancangan basis pengetahuan untuk sistem pakar. Perancangan akuisisi pengetahuan ini dimulai dengan membuat tabel yang berisikan informasi mengenai jenis gangguan, kriteria diagnosis, faktor lain yang mempengaruhi dan bagaimana cara penanganannya. Dalam penelitan kali ini, jenis gangguan yang dikelompokkan adalah sebanyak 10 jenis gangguan dengan 40 jenis gejala.

Identifikasi masukkan (input) tahapan untuk pengumpulan data atau informasi yang mendukung dalam rancang bangun aplikasi sistem pakar diagnosis gangguan emosional pada anak. Data masukkan (input) diperoleh dari jawaban hasil pertanyaan yang akan diajukan oleh sistem. Selain data jawaban, data masukkan (input) lainnya adalah berupa biodata anak dan juga pertanyaan yang diajukan untuk pakar dari pengguna sistem pakar diagnosis gangguan emosional pada anak.

Identifikasi keluaran (output) merupakan tahapan untuk menentukan rancangan hasil dalam bentuk kesimpulan (diagnosis) yang diperoleh dari jawaban pertanyaan yang diberikan sistem kepada pengguna. Sistem akan mengolah setiap jawaban yang diberikan pengguna kepada sistem yang setiap jawabannya akan mempengaruhi kesimpulan yang didapat. Informasi yang diperoleh oleh pengguna atas jawaban yang sudah diberikan adalah berupa diagnosis jenis gangguan emosional yang terdapat pada anak dan bagaimana langkah tepat yang harus diambil dalam proses penanganannya.

Sasaran dari aplikasi ini adalah menghasilkan sebuah sistem yang dapat memberikan jawaban berupa suatu jenis gangguan dari hasil beberapa gejala yang telah dipilih oleh pengguna. Fitur utama dari aplikasi sistem pakar adalah sebagai berikut:

1. Mengisikan biodata anak yang akan diperiksa

2. Melakukan diagnosis terhadap gejala-gejala

3. Menampilkan hasil diagnosis beserta definisi dan penanganan terhadap gangguan tersebut

4. Login pakar maupun admin

Fitur tambahan dari aplikasi sistem pakar adalah:

1. Menyediakan fitur tanya pakar

2. Menyediakan artikel

Langkah selanjutnya setelah menentukan kebutuhan sistem adalah membuat desain atau gambaran umum dari sistem dengan menggunakan metode terstruktur yaitu context diagram, data flow diagram serta penggambaran proses melalui diagram alir.

\section{B. Proses Desain Sistem}

Tahapan selanjutnya adalah proses desain sistem sebagai gambaran dasar bentuk sistem. Dalam melakukan desain sistem terdapat beberapa hal yang harus dibuat yaitu desain proses kerja, desain basis data dan desain tampilan sistem. Pemodelan desain proses kerja menggunakan metode terstruktur, yaitu context diagram dan DFD (data flow diagram) level 1

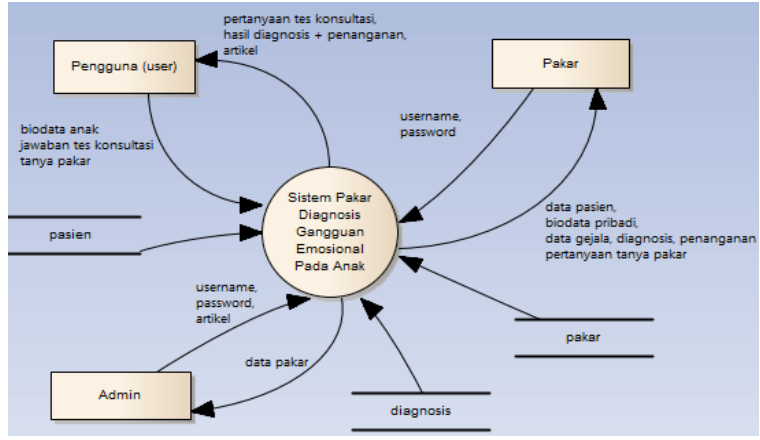

Gambar 2. Diagram Konteks Sistem Pakar

Gambar 2 merupakan diagram konteks dari aplikasi sistem pakar merupakan gambaran umum tentang sistem meliputi entitas luar (pengguna, pakar dan admin), proses (sistem pakar diagnosis gangguan emosional pada anak), penyimpanan data (pasien, diagnosis dan pakar) serta bagaimana aliran datanya. Proses yang lebih rinci dari diagram konteks tersebut dapat dijabarkan lagi dalam bentuk Data Flow Diagram (DFD) level 0 yang akan ditunjukkan pada gambar 3 .

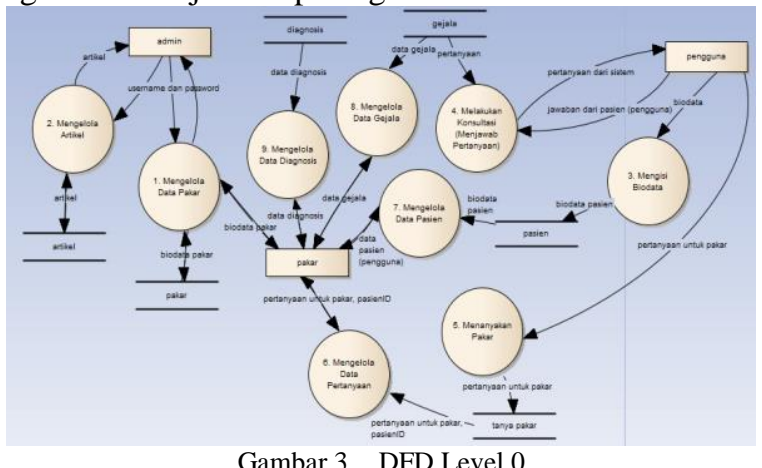

Gambar 3. DFD Level 0 
Gambar 3 menunjukkan DFD Level 0 yang menggambarkan proses apa saja yang terdapat dalam sistem pakar. Dalam gambar tersebut, terdapat sembilan proses utama yang menghubungkan entitas maupun proses ke penyimpanan data. Sembilan proses tersebut diantaranya adalah:

1. Proses 1: mengelola data pakar. Beberapa proses yang dapat dilakukan dalam mengelola data pakar diantaranya adalah memberi username dan password untuk pakar, menghapus data pakar dan mengubah username dan password untuk pakar.

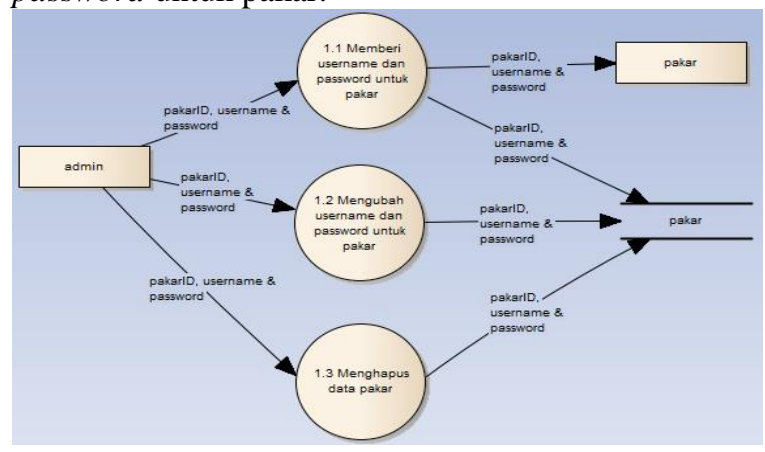

Gambar 4. DFD Level 1 Proses 1 (Mengelola Data Pakar)

2. Proses 2: mengelola data artikel. Beberapa proses yang dapat dilakukan diantaranya adalah mengisi atau menulis artikel, menghapus artikel dan mengubah isi artikel. Entitas yang terlibat hanya admin saja dengan penyimpanan data di datastore artikel.

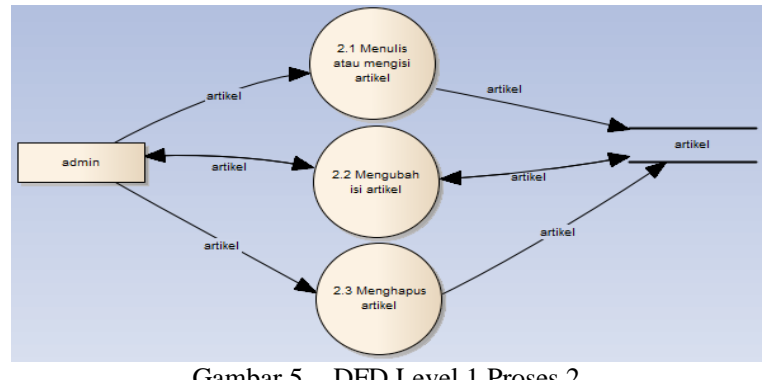

3. Proses 3: mengelola data pertanyaan. Beberapa proses yang dapat dilakukan dalam mengelola data pertanyaan adalah melihat daftar pertanyaan yang diberikan oleh pengguna untuk pakar, menjawab pertanyaan serta menghapus pertanyaan.

4. Proses 4: mengelola data pasien. Beberapa proses yang dapat dilakukan dalam mengelola data pasien diantaranya adalah melihat data pasien dan menghapus data pasien. Entitas yang terlibat diantaranya adalah pakar dan pasien dengan penyimpanan data di datastore pasien.

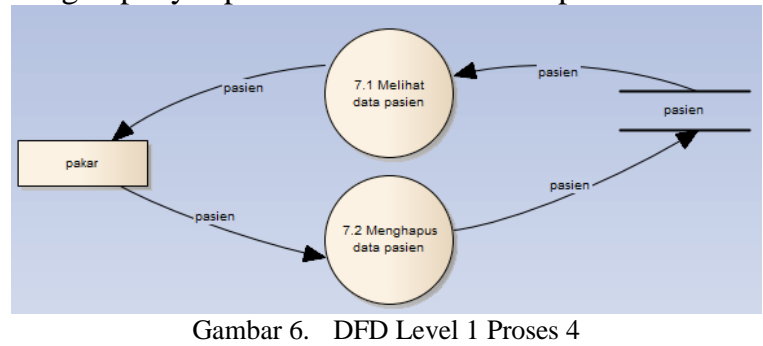

Setelah melakukan perancangan alur kerja sistem, tahapan selanjutnya adalah melakukan perancangan basisdata. Dalam melakukan perancangan basisdata, beberapa tahapan yang dilakukan adalah menentukan entitas apa saja yang akan terlibat. Entitas yang terlibat dan dibuat sendiri dalam penelitian ini sebanyak delapan buah, diantaranya: user, pakar, pasien, gejala, diagnosis, gangguan, artikel dan tanya pakar. Setelah menentukan entitas apa saja yang terlibat, tahapan selanjutnya adalah menentukan atribut dari tiap entitas tersebut. Tabel 1hingga tabel 8 adalah perincian dari atribut pada tiap-tiap entitas.

Tabel 1. Tabel User

\begin{tabular}{|l|l|l|l|l|}
\hline No & Kolom & Tipe Data & Keterangan & Deskripsi \\
\hline 1. & userID & VARCHAR(3) & Primary Key & Kolom ID untuk admin \\
\hline 2. & Email & VARCHAR(30) & - & Kolom untuk email admin \\
\hline 2. & Username & VARCHAR(20) & - & $\begin{array}{l}\text { Kolom untuk username } \\
\text { admin }\end{array}$ \\
\hline 3. & Password & VARCHAR(32) & - & $\begin{array}{l}\text { Kolom untuk password } \\
\text { admin }\end{array}$ \\
\hline
\end{tabular}

\begin{tabular}{|c|c|c|c|c|}
\hline No & Kolom & Tipe Data & Keterangan & Deskripsi \\
\hline 1. & pakarID & INT(3) & Primary Key & Kolom ID untuk pakar \\
\hline 2. & nama_pakar & VARCHAR(30) & - & Kolom untuk nama pakar \\
\hline 3. & tgl_lahir & DATETIME & - & $\begin{array}{l}\text { Kolom untuk tanggal lahir } \\
\text { pakar }\end{array}$ \\
\hline 4. & alamat_pakar & VARCHAR $(100)$ & - & Kolom untuk alamat pakar \\
\hline 5. & email & VARCHAR $(50)$ & - & Kolom untuk email pakar \\
\hline 6. & no_hp & VARCHAR(15) & - & Kolom untuk no hp pakar \\
\hline 7. & alamat_kantor & VARCHAR $(100)$ & & \\
\hline 8. & notes & VARCHAR(500) & - & $\begin{array}{l}\begin{array}{l}\text { Kolom } \\
\text { pakar }\end{array} \\
\text { pantuk username }\end{array}$ \\
\hline 9. & foto & VARBINARY & - & $\begin{array}{l}\text { Kolom untuk password } \\
\text { pakar }\end{array}$ \\
\hline 10. & User & VARCHAR(3) & $\begin{array}{l}\text { Navigation } \\
\text { Property }\end{array}$ & $\begin{array}{l}\text { Menentukan relasi ke tabel } \\
\text { user }\end{array}$ \\
\hline
\end{tabular}

\section{Tabel 3. Tabel Pasien}

\begin{tabular}{|c|c|c|c|c|}
\hline No & Kolom & Tipe Data & Keterangan & Deskripsi \\
\hline 1. & pasienID & INT & Primary Key & Kolom ID untuk pasien \\
\hline 2. & nama_anak & VARCHAR $(25)$ & - & Kolom untuk nama anak \\
\hline 3. & Usia & INT & - & Kolom untuk usia anak \\
\hline 4. & Jenkel & VARCHAR(10) & - & $\begin{array}{l}\text { Kolom untuk jenis kelamin } \\
\text { anak }\end{array}$ \\
\hline 5. & gol_darah & VARCHAR(2) & - & $\begin{array}{l}\text { Kolom untuk golongan darah } \\
\text { anak }\end{array}$ \\
\hline 6. & alamat & VARCHAR $(50)$ & - & Kolom untuk alamat anak \\
\hline 7. & nama_ayah & $\operatorname{VARCHAR}(25)$ & - & Kolom untuk nama ayah anak \\
\hline 8. & nama ibu & $\operatorname{VARCHAR}(25)$ & - & Kolom untuk nama ibu anak \\
\hline 9. & email_ortu & VARCHAR(25) & - & $\begin{array}{l}\text { Kolom untuk alamat email } \\
\text { orang tua }\end{array}$ \\
\hline 10. & waktuTes & DateTime & - & $\begin{array}{l}\text { Kolom untuk waktu pengguna } \\
\text { melakukan tes }\end{array}$ \\
\hline 11. & Gejala & VARCHAR(128) & $\begin{array}{l}\text { Navigation } \\
\text { Property }\end{array}$ & $\begin{array}{l}\text { Kolom untuk menunjukan } \\
\text { relasi dengan tabel gejala }\end{array}$ \\
\hline 12. & diagnosisID & VARCHAR(3) & $\begin{array}{l}\text { Navigation } \\
\text { Property }\end{array}$ & $\begin{array}{l}\text { Kolom untuk menunjukkan } \\
\text { relasi dengan tabel diagnosis }\end{array}$ \\
\hline
\end{tabular}

Tabel 4. Tabel Gejala

\begin{tabular}{|l|l|l|l|l|}
\hline No & Kolom & Tipe Data & Keterangan & Deskripsi \\
\hline 1. & gejalaID & VARCHAR(3) & Primary Key & $\begin{array}{l}\text { Kolom ID untuk } \\
\text { gejala }\end{array}$ \\
\hline 2. & nama_gejala & VARCHAR(100) & - & $\begin{array}{l}\text { Kolom untuk nama } \\
\text { gejala }\end{array}$ \\
\hline 3. & pertanyaan_sistem & VARCHAR(500) & - & $\begin{array}{l}\text { Kolom untuk } \\
\text { pertanyaan sistem }\end{array}$ \\
\hline 4. & gejala_gejalaID & VARCHAR(128) & $\begin{array}{l}\text { Navigation } \\
\text { Properties }\end{array}$ & $\begin{array}{l}\text { Kolom untuk } \\
\text { menunjukkan relasi } \\
\text { ke tabel gejala }\end{array}$ \\
\hline 5. & gejala_gejalaID1 & VARCHAR(128) & $\begin{array}{l}\text { Navigation } \\
\text { Properties }\end{array}$ & $\begin{array}{l}\text { Kolom untuk } \\
\text { menunjukkan relasi } \\
\text { ke tabel gejala }\end{array}$ \\
\hline 6. & diagnosisSakit_gangguanID & VARCHAR(128) & $\begin{array}{l}\text { Navigation } \\
\text { Properties }\end{array}$ & $\begin{array}{l}\text { Kolom untuk } \\
\text { menunjukkan relasi } \\
\text { ke tabel diagnosis }\end{array}$ \\
\hline
\end{tabular}

Tabel 5. Tabel Diagnosis

\begin{tabular}{|l|l|l|l|l|}
\hline No & Kolom & Tipe Data & Keterangan & Deskripsi \\
\hline 1. & diagnosisID & VARCHAR(3) & Primary Key & Kolom ID untuk diagnosis \\
\hline 2. & gangguanID & VARCHAR(3) & - & Kolom ID untuk gangguan \\
\hline 3. & gejalaID & VARCHAR(1000) & - & Kolom ID untuk gejala \\
\hline
\end{tabular}

Tabel 6. Tabel Gangguan

\begin{tabular}{|l|l|l|l|l|}
\hline No & Kolom & Tipe Data & Keterangan & Deskripsi \\
\hline 1. & gangguanID & VARCHAR(3) & Primary Key & Kolom ID untuk admin \\
\hline 2. & nama gangguan & VARCHAR(50) & - & Kolom untuk nama gangguan \\
\hline 3. & Definisi & VARCHAR(300) & - & Kolom untuk definisi gangguan \\
\hline 4. & Penanganan & VARCHAR(2000) & - & $\begin{array}{l}\text { Kolom untuk penanganan } \\
\text { gangguan }\end{array}$ \\
\hline
\end{tabular}


Tabel 7. Tabel Artikel

\begin{tabular}{|l|l|l|l|l|}
\hline No & Kolom & Tipe Data & Keterangan & Deskripsi \\
\hline 1. & artikelID & INT & Primary Key & Kolom ID untuk artikel \\
\hline 2. & Judul & VARCHAR(80) & - & Kolom untuk judul artikel \\
\hline 3. & isi_artikel & VARCHAR(2000) & - & Kolom untuk isi artikel \\
\hline 4. & terakhirDiperbaharui & DateTime & - & $\begin{array}{l}\text { Kolom untuk waktu } \\
\text { kapan terakhir kali artikel } \\
\text { diperbaharui }\end{array}$ \\
\hline 5. & waktuDibuat & DateTime & - & $\begin{array}{l}\text { Kolom untuk waktu } \\
\text { kapan artikel pertama kali } \\
\text { ditulis admin }\end{array}$ \\
\hline
\end{tabular}

Tabel 8. Tabel tanya_pakar

\begin{tabular}{|c|c|c|c|c|}
\hline No & Kolom & Tipe Data & Keterangan & Deskripsi \\
\hline 1. & pertanyaanID & INT & Primary Key & $\begin{array}{l}\text { Kolom ID untuk pertanyaan } \\
\text { tanya pakar }\end{array}$ \\
\hline 2. & email_user & VARCHAR $(50)$ & - & Kolom untuk email user \\
\hline 3. & Pertanyaan & $\operatorname{VARCHAR}(250)$ & - & Kolom untuk pertanyaan \\
\hline$\frac{4 .}{5 .}$ & $\begin{array}{l}\text { jawabanPakar } \\
\text { Terjawab }\end{array}$ & $\begin{array}{l}\text { VARCHAR }(500) \\
\text { BIT }\end{array}$ & - & $\begin{array}{l}\text { Kolom untuk jawaban pakar } \\
\text { Kolom untuk }\end{array}$ \\
\hline 6. & waktuBertanya & Datetime & - & $\begin{array}{l}\text { pertanyaan } \\
\text { Kolom untuk waktu kapan } \\
\text { pertanyaan } \\
\text { diajukan }\end{array}$ \\
\hline 7. & waktuMenjawab & Datetime & - & $\begin{array}{l}\text { penguna } \\
\text { Kolom untuk waktu kapan } \\
\text { pertanyaan dijawab oleh } \\
\text { pakary }\end{array}$ \\
\hline
\end{tabular}

Setelah menentukan entitas dan atribut yang dimiliki dari tiap entitas tersebut, tahapan selanjutnya adalah menggambarkan keterkaitan hubungan antar entitas tersebut (Diagram ER). Diagram ER yang digunakan untuk memperlihatkan hubungan antar entitas dalam sistem pakar diagnosis gangguan emosional pada anak adalah sebagai berikut ini

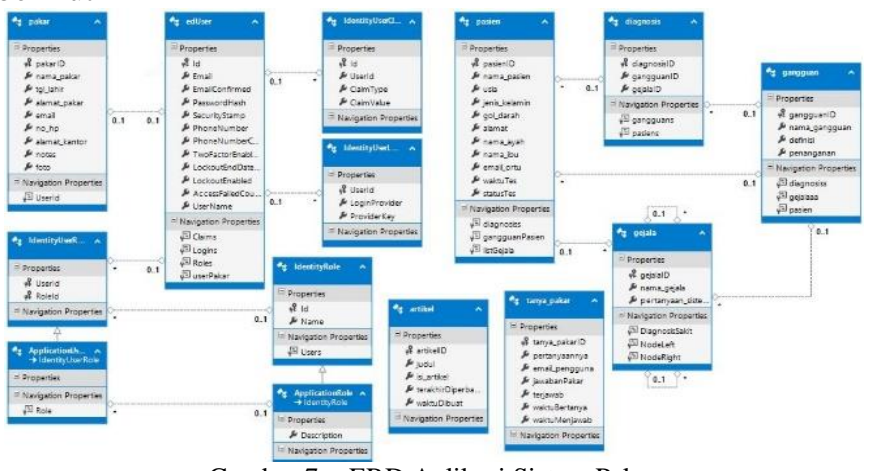

Gambar 7. ERD Aplikasi Sistem Pakar

Dalam melakukan rancang bangun sistem pakar, terdapat suatu tahapan yang disebut dengan perancangan basis pengetahuan. Desain basis pengetahuan berguna untuk memberikan gambaran dari aturan-aturan yang digunakan sistem untuk melakukan diagnosis penyakit. Aturan-aturan tersebut dapat terbentuk setelah mengumpulkan data-data dari pakar. Tabel 9 dijabarkan kode gejala dan data gejala yang berhubungan dengan penyakit yang menjadi bahan diagnosis sistem dan isi tabel basisdata sistem.

Tabel 9. Tabel Daftar Gejala

\begin{tabular}{|c|l|}
\hline gejalaID & nama_gejala \\
\hline G01 & Gejala fisik \\
\hline G02 & Gejala psikologis \\
\hline G03 & Kecemasan saat harus berada di situasi yang ramai \\
\hline G04 & Kecemasan ketika pergi ke tempat umum \\
\hline G05 & Kecemasan ketika berpergian sendiri \\
\hline G06 & $\begin{array}{l}\text { Berusaha menghindar dari situasi ramai atau di tempat } \\
\text { umum atau berpergian sendiri }\end{array}$ \\
\hline G07 & Rasa cemas ketika berada diluar lingkungan keluarga \\
\hline G08 & Memiliki ketakutan sendiri pada situasi tertentu \\
\hline G09 & Pengaruh obat-obatan \\
\hline G10 & $\begin{array}{l}\text { Kecemasan dalam keadaan yang biasa saja (cemas tanpa } \\
\text { sebab) yang tidak perlu dikhawatirkan }\end{array}$ \\
\hline G11 & Sulit berkonsentrasi \\
\hline G12 & Memiliki kekhawatiran akan nasib buruk \\
\hline
\end{tabular}

\begin{tabular}{|l|l|}
\hline G13 & Tampak depresi (sifatnya sementara) \\
\hline G14 & Ketegangan motoric \\
\hline G15 & Overaktivitas otonomik \\
\hline G16 & Kebutuhan berlebihan untuk ditenangkan \\
\hline G17 & Stress akan kehidupan yang penuh masalah \\
\hline G18 & $\begin{array}{l}\text { Ketidakstabilan menetap dari afek perasaan (suasana } \\
\text { perasaan) }\end{array}$ \\
\hline G19 & Afek depresif \\
\hline G20 & Afek yang meninggi atau berubah \\
\hline G21 & Peningkatan aktivitas \\
\hline G22 & Gejala dimulai sejak dini \\
\hline G23 & Kehilangan minat dan kegembiraan \\
\hline G24 & $\begin{array}{l}\text { Berkurangnya energy yang menuju meningkatnya keadaan } \\
\text { mudah lelah }\end{array}$ \\
\hline G25 & Konsentrasi dan perhatian berkurang \\
\hline G26 & Harga diri dan kepercayaan diri berkurang \\
\hline G27 & Selalu merasa bersalah atau tidak berguna \\
\hline G28 & Memiliki pandangan masa depan yang suram \\
\hline G29 & Mencoba melakukan bunuh diri \\
\hline G30 & Tidur terganggu \\
\hline G31 & Nafsu makan berkurang \\
\hline G32 & Gangguan tersebut dialami sekurang-kurangnya 2 minggu \\
\hline G33 & Gejala tampak selama 1 bulan \\
\hline G34 & Gejala tampak setiap hari \\
\hline G35 & Gejala tampak selama 1 tahun atau lebih \\
\hline G36 & Memiliki dampak kelancaran aktivitas \\
\hline G37 & Overaktivitas otonomik \\
\hline G38 & Gejala tampak setiap hari \\
\hline G40 & Stress seolah merasa kehidupan yang penuh masalah \\
\hline Afek Depresif \\
\hline Galam & motel representasi pengetahuan kaidah produks \\
\hline
\end{tabular}

Dalam model representasi pengetahuan kaidah produksi, terdapat beberapa tahapan yang harus dilalui dari pengetahuan yang didapatkan. Tahapan tersebut diantaranya adalah menyajikan pengetahuan yang berhasil didapatkan dalam bentuk tabel keputusan kemudian dari tabel keputusan dibuat menjadi pohon keputusan.

Tabel 10. Tabel Keputusan

\begin{tabular}{|c|c|c|c|c|c|c|c|c|c|c|}
\hline \multirow{2}{*}{ Gejala } & \multicolumn{10}{|c|}{ Gangguan } \\
\hline & A01 & $\mathbf{A 0 2}$ & $\mathbf{A 0 3}$ & A04 & A05 & A06 & A07 & A08 & A09 & A10 \\
\hline \multicolumn{11}{|l|}{ G01 } \\
\hline \multicolumn{11}{|l|}{ G02 } \\
\hline \multicolumn{11}{|l|}{ G03 } \\
\hline \multicolumn{11}{|l|}{ G04 } \\
\hline \multicolumn{11}{|l|}{ G05 } \\
\hline \multicolumn{11}{|l|}{ G06 } \\
\hline \multicolumn{11}{|l|}{ G07 } \\
\hline \multicolumn{11}{|l|}{ G08 } \\
\hline \multicolumn{11}{|l|}{ G09 } \\
\hline \multicolumn{11}{|l|}{ G10 } \\
\hline \multicolumn{11}{|l|}{ G11 } \\
\hline \multicolumn{11}{|l|}{ G12 } \\
\hline \multicolumn{11}{|l|}{ G13 } \\
\hline \multicolumn{11}{|l|}{ G14 } \\
\hline \multicolumn{11}{|l|}{ G15 } \\
\hline \multicolumn{11}{|l|}{ G16 } \\
\hline \multicolumn{11}{|l|}{ G17 } \\
\hline \multicolumn{11}{|l|}{ G18 } \\
\hline \multicolumn{11}{|l|}{ G19 } \\
\hline \multicolumn{11}{|l|}{ G20 } \\
\hline \multicolumn{11}{|l|}{ G21 } \\
\hline \multicolumn{11}{|l|}{ G22 } \\
\hline \multicolumn{11}{|l|}{ G23 } \\
\hline G24 & & & & & & & & & & \\
\hline G25 & & & & & & & & & & \\
\hline G26 & & & & & & & & & & \\
\hline G27 & & & & & & & & & & \\
\hline G28 & & & & & & & & & & \\
\hline G29 & & & & & & & & & & \\
\hline G30 & & & & & & & & & & \\
\hline G31 & & & & & & & & & & \\
\hline G32 & & & & & & & & & & \\
\hline G33 & & & & & & & & & & \\
\hline G34 & & & & & & & & & & \\
\hline G35 & & & & & & & & & & \\
\hline
\end{tabular}




\begin{tabular}{|l|l|l|l|l|l|l|l|l|l|l|}
\hline G36 & & & & & & & & & & \\
\hline G37 & & & & & & & & & & \\
\hline G38 & & & & & & & & & & \\
\hline G39 & & & & & & & & & & \\
\hline G40 & & & & & & & & & & \\
\hline
\end{tabular}

Keterangan:

: tidak terdapat gejala tersebut

: gejala dari gangguan

Selanjutnya adalah menggambarkan tabel keputusan ke dalam pohon keputusan

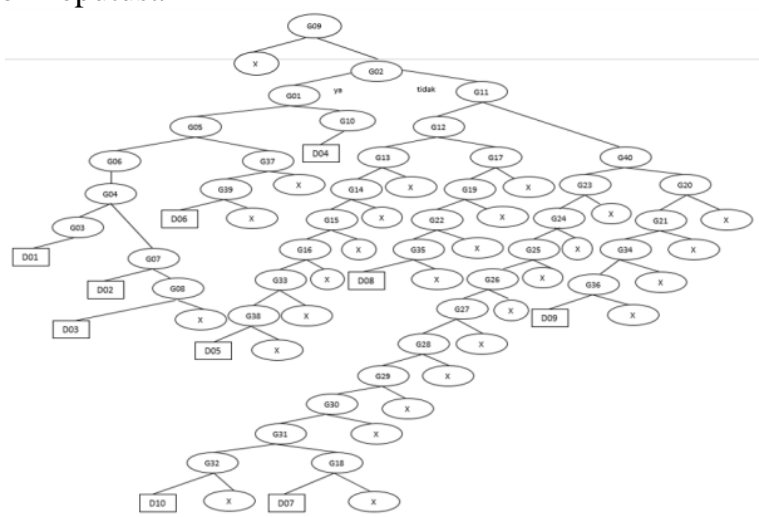

Gambar 8. Pohon Keputusan Aplikasi Sistem Pakar

Setelah membuat tabel keputusan dan pohon keputusan, selanjutnya adalah menyusun kaidah produksi. Tabel 11 berikut ini menggambarkan kaidah produksi pada sistem pakar diagnosis gangguan emosional pada anak.

Tabel 11. Kaidah Produksi Sistem Pakar

\begin{tabular}{|c|c|}
\hline No & Aturan \\
\hline 1. & $\begin{array}{l}\text { R1 : IF G02 AND G01 AND G05 AND G06 AND G04 AND } \\
\text { G03 THEN D01 }\end{array}$ \\
\hline 2. & $\begin{array}{l}\text { R2 : IF G02 AND G01 AND G05 AND G06 AND G07 THEN } \\
\text { D02 }\end{array}$ \\
\hline 3. & $\begin{array}{l}\text { R3 : IF G02 AND G01 AND G05 AND G06 AND G08 OR } \\
\text { G09 OR G10 OR G11 OR G12 THEN D03 }\end{array}$ \\
\hline 4. & R4 : IF G02 AND G01 AND G19 AND G21 THEN D06 \\
\hline 5. & $\begin{array}{l}\text { R5 : IF G15 AND G16 AND G17 AND G18 AND G19 AND } \\
\text { G30 AND G37 AND G38 THEN D05 }\end{array}$ \\
\hline 6. & $\begin{array}{l}\text { R6 : IF G15 AND G21 AND G23 AND G26 AND G39 THEN } \\
\text { D08 }\end{array}$ \\
\hline 7. & R7 : IF G02 AND G14 THEN D04 \\
\hline 8. & $\begin{array}{l}\text { R8 : IF G23 AND G27 AND G28 AND G29 AND G30 AND } \\
\text { G31 AND G32 AND G33 AND G34 AND G35 AND } \\
\text { G36 THEN D10 }\end{array}$ \\
\hline 9. & $\begin{array}{l}\text { R9 : IF G23 AND G27 AND G28 AND G29 AND G30 AND } \\
\text { G31 AND G32 AND G33 AND G34 AND G22 THEN } \\
\text { D07 }\end{array}$ \\
\hline 10. & R10 : IF G24 AND G25 AND G38 AND G40 THEN D09 \\
\hline
\end{tabular}

Tahapan selanjutnya adalah melakukan perancangan mesin inferensi sistem pakar. Gambaran tersebut digambarkan dalam diagram alir dari aplikasi sistem pakar yang ditunjukkan pada gambar berikut.

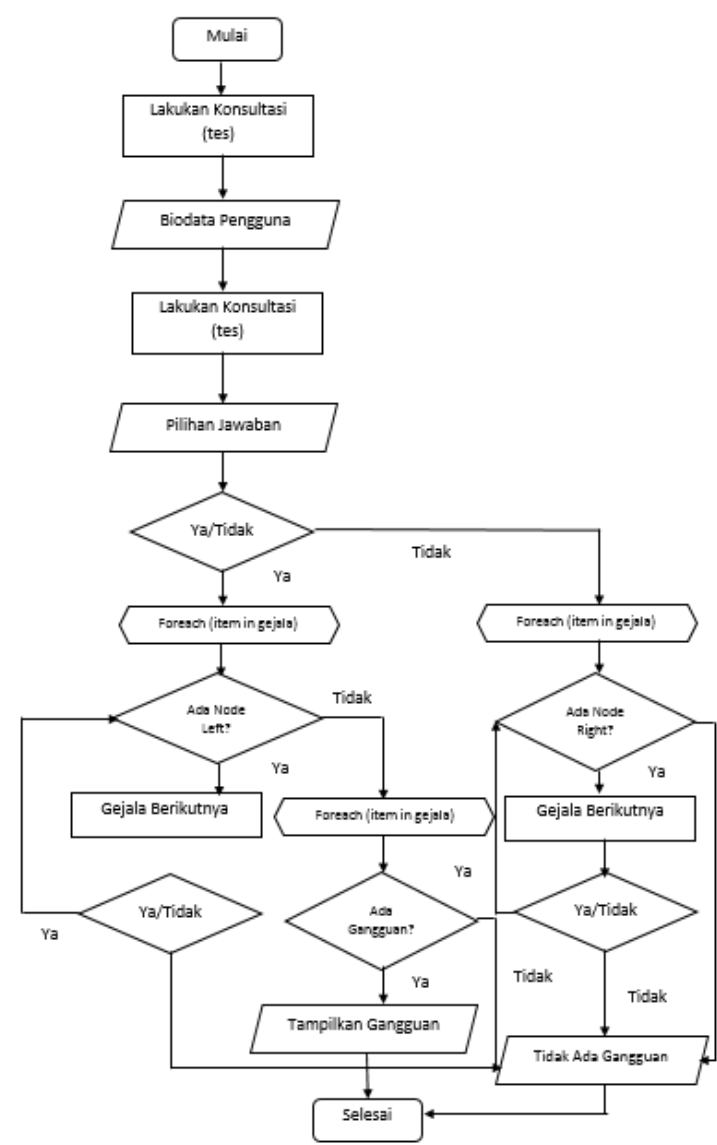

Gambar 9. Diagram Alir Sistem Pakar

Perancangan atarmuka bertujuan untuk memberikan gambaran tentang aplikasi yang akan dibangun, sehingga dapat memberikan gambaran untuk calon pengguna aplikasi. Selain itu, dengan melakukan perancangan antarmuka diharapkan dapat mempermudah dalam melakukan implementasi serta memudahkan pengembang sistem dalam membangun aplikasi. Perancangan sistem pakar diagnosis gangguan emosional pada anak berbasis aplikasi website, memiliki beberapa rancangan antarmuka seperti berikut ini

1. Tampilan awal dari sistem pakar

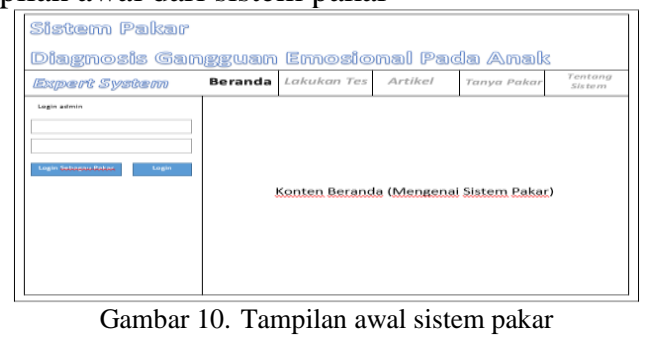

2. Tampilan untuk lakukan tes (isi biodata)

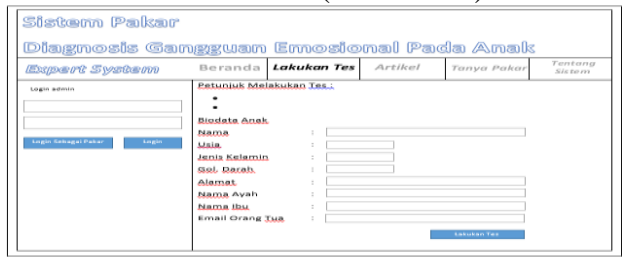

Gambar 11. Tampilan untuk lakukan tes 
3. Tampilan untuk menjawab pertanyaan

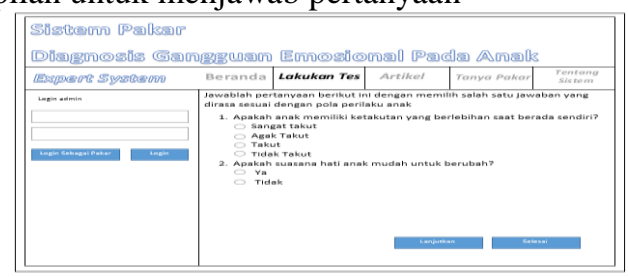

Gambar 12. Tampilan Menjawab Pertanyaan

4. Tampilan untuk melihat hasil diagnosis

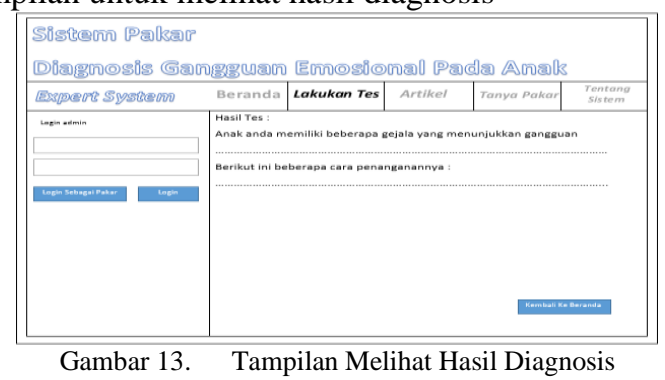

5. Tampilan untuk artikel

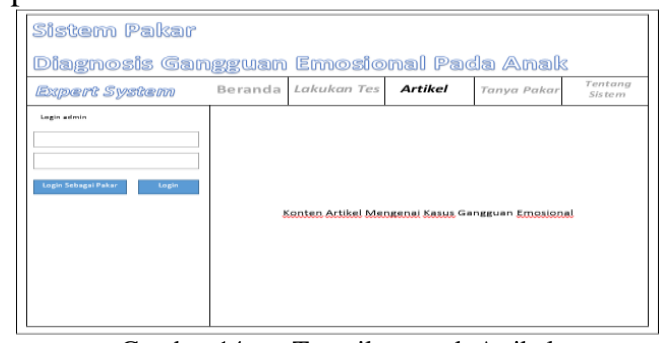

Gambar 14. Tampilan untuk Artikel

6. Tampilan untuk tanya pakar

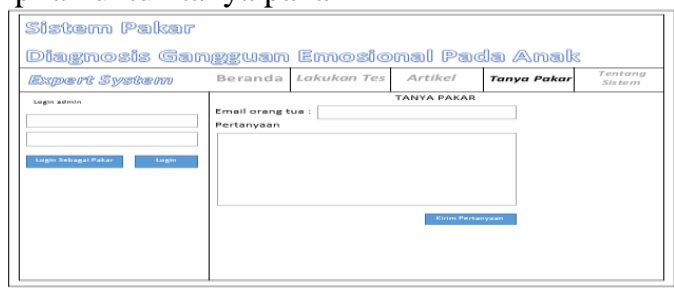

Gambar 15. Tampilan untuk Tanya Pakar

7. Tampilan untuk tentang sistem

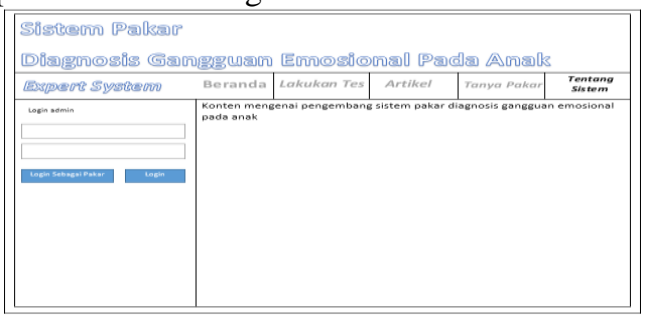

Gambar 16. Tampilan untuk Tentang Sistem

8. Tampilan untuk login admin

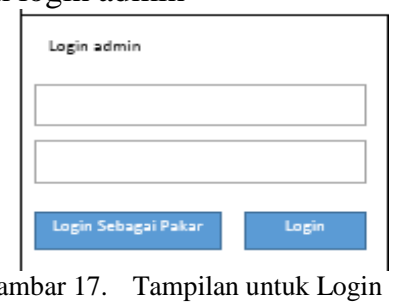

9. Tampilan beranda admin

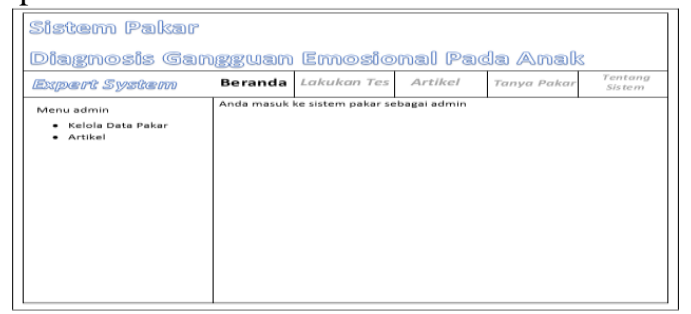

Gambar 18. Tampilan Beranda Admin

10. Tampilan beranda pakar

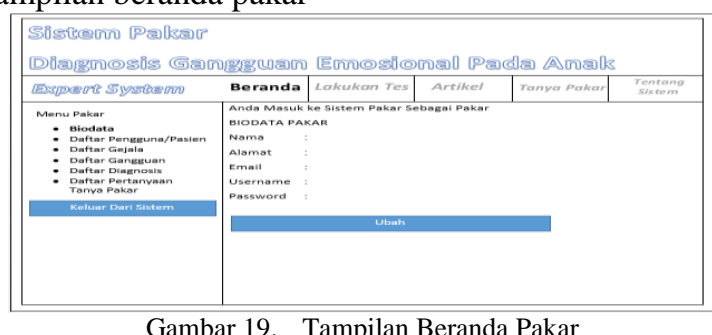

Gambar 19. Tampilan Beranda Pakar

IV. IMPLEMENTASI DAN PENGUJIAN

\section{A. Tahap Pembuatan Sistem}

Tahapan awal yang dilakukan dalam melakukan implementasi sistem adalah pembuatan basisdata, pemodelan basisdata yang dipilih adalah codefirst, yaitu membangun basis data dengan menggunakan baris kode yang nantinya diintegrasikan dengan Entity Framework untuk menerjemahkannya ke dalam basisdata SQL Server Local Database.

Dalam membuat basisdata beberapa tahapan yang dilakukan diantaranya:

1. Installasi Entity-Framework

Installasi Entity-Framework memiliki tujuan agar kode program dengan basisdata dapat terkoordinasi sesuai dengan perancangan sebelumnya. Installasi Entity-Framework dilakukan pada Package Manager Console yang terdapat pada menu Tools. Pada console tersebut berikan perintah InstallPackage EntityFramework.

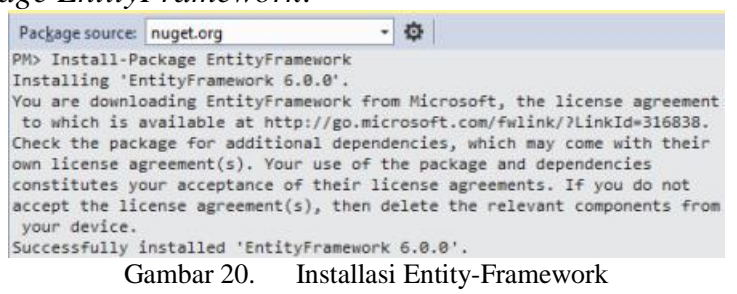

2. Pemrograman Model

Pemrograman model dilakukan untuk membentuk tabeltabel yang terdapat pada basis data rancang bangun sistem pakar diagnosis gangguan emosional pada anak. Dalam melakukan pemrograman model, setiap model diberikan referensi

library

System.ComponentModel.DataAnotation.Schema yang berfungsi untuk meggunakan keterangan seperti class tersebut akan terbentuk menjadi tabel, variabel tidak boleh null, serta keterangan lainnya sesuai dengan kebutuhan kolom-kolom untuk tabel pada basisdata yang akan dibentuk. 
Beberapa class yang nantinya dibentuk menjadi tabel, diantaranya adalah: pasien, gangguan, gejala, diagnosis, pakar, tanya_pakar, artikel dan edUser. Salah satu contoh kode program dalam pemrograman model adalah sebagai berikut (class gejala).

[Table("gejala")]

public class gejala

[Required]

public String gejalaID \{ get; set; \}

[Required, MaxLength(100)]

public String nama_gejala \{ get; set; \}

[Required, MaxLength(500)]

public String pertanyaan_sistem \{ get; set;

\}

public List<gejala> NodeLeft \{get; set; \}

public List<gejala> NodeRight \{ get; set; \}

public gangguan Diagnosissakit \{ get; set; \}

3. DAL (Data Access Layer)

Data Access Layer merupakan salah satu dari bagian program yang menangani konteks basisdata. Class konteks basisdata merupakan class utama yang mengkoordinasikan antara fungsionalitas entity framework terhadap model yang sebelumnya telah dibuat. Dalam melakukan pemrograman rancang bangun sistem pakar diagnosis gangguan emosional berbasis aplikasi website, class konteks basisdata diberikan nama edContext.cs yang diturunkan dari class System.Data.Entity. DbContext.

4. Migrasi

Codefirst-migration merupakan salah satu fitur dari entity framework yang berguna untuk memecahkan masalah ketika melakukan perubahan pada bagian model. Dengan menggunakan metode migrasi, database akan tetap sinkron dengan perubahan yang terjadi di model sampai aplikasi benarbenar dideploy pada tahap produksi.

Tahapan dalam melakukan migrasi adalah meniadakan database initializer pada webconfig dan memberikan nama pada basisdata untuk aplikasi seperti pada kode program berikut ini: $<$ connectionstrings >

<add name="edContext" connectionstring="Data

Source $=($ LocalDb $) \backslash v 11.0$; AttachDbFilename=| DataDire

ctory| \aspnet-bismillah ta-fix9.mdf; Initial

Catalog=bismillah_ta; Integrated Security=SSPI"

providerName="System. Data.SqlClient" />

$</$ connectionstrings $>$

Pada penelitian ini nama basis data yang digunakan adalah aspnet-bismillah_ta-fix9.mdf. Tahapan selanjutnya adalah mengaktifkan migrasi melalui Package Manager Console yang terdapat pada menu Tools. Berikan perintah pada console :

PM > Enable-Migrations -ContextTypeName : (nama class konteks). Proses mengaktifkan migrasi ditunjukkan pada gambar 21 .

$$
\begin{aligned}
& \text { PM> Enable-Migrations -ContextTypeName:edContext } \\
& \text { Checking if the context targets an existing database... } \\
& \text { Code First Migrations enabled for project bismillah_ta. } \\
& \text { Gambar 21. Mengaktifkan Migrasi }
\end{aligned}
$$

Setelah berhasil mengaktifkan migrasi, maka akan membentuk suatu folder baru yang bernama Migrations. Tahapan selanjutnya adalah dengan menambahkan migrasi yang bertujuan memberi gambaran kepada pengembang sistem tentang perubahan apa saja yang dilakukan dalam model, jika penambahan migrasi baru dilakukan pertama kali maka barisan kode yang akan ditunjukkan kepada pengguna adalah gambaran mengenai basisdata yang akan terbentuk dengan menyesuaikan pada model yang sudah diprogram sebelumnya. Cara menambahkan migrasi ditunjukkan pada gambar 22.

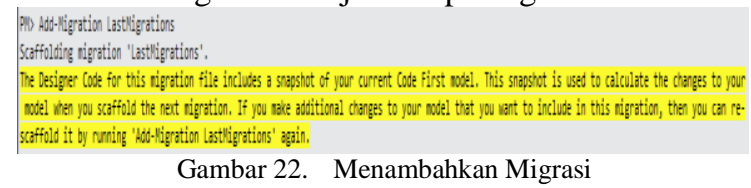

Setelah melakukan migrasi pada SQL Server Local Database sudah terbentuk tabel-tabel basisdata sesuai dengan apa yang sebelumnya sudah dikodekan di model maupun di data access layer. Susunan tabel-tabel basisdata untuk sistem pakar diagnosis gangguan emosional pada anak berbasis aplikasi website ditunjukkan pada gambar 23.

$$
\begin{aligned}
& 4 \text { edContext (bismillah_ta) } \\
& 4 \text { Tables } \\
& \triangleright \text { 囲_MigrationHistory } \\
& \text { D 囲_Mig } \\
& \text { D囲 artikel } \\
& \triangleright \text { 柬 diagnosis } \\
& \triangleright \text { 柬 ganggua } \\
& \triangleright \text { 囲 gejala } \\
& \triangleright \text { 柬 Pakar } \\
& \triangleright \text { 囲 pasien } \\
& \triangleright \text { 团 Roles } \\
& \triangleright \text { 囲 tanya_pakar } \\
& \text { D 田 User } \\
& \triangleright \text { 团 UserClaim } \\
& \checkmark \text { Userlogin } \\
& \triangleright \text { 囲 UserLogi } \\
& \text { Views } \\
& D \text { Stored Procedures } \\
& \triangleright \text { Functions } \\
& \triangleright \backsim \text { Synonyms } \\
& \triangleright \text { Types } \\
& -
\end{aligned}
$$

Gambar 23. Struktur Tabel Basisdata Aplikasi Sistem Pakar

\section{Update-Database}

Tabel-tabel yang sudah terbentuk sebelumnya masih memiliki nilai null pada tiap-tiap atribut yang terdapat di dalam tabel. Sesuai dengan perancangan sebelumnya, beberapa tabel yang akan mendapatkan inisialisai nilai adalah tabel gejala, tabel gangguan, tabel artikel dan tabel diagnosis. Untuk dapat melakukan inisialisasi nilai-nilai atribut pada tabel di basisdata, maka hal yang dilakukan adalah memberikan kode program di class configuration pada method Seed. Kode program yang terdapat pada method Seed tersebut dijalankan dengan memberikan perintah update-database pada Package Console Manager hingga muncul keterangan Running Seed Method yang berarti method seed berhasi dijalankan dan data sudah masuk ke basisdata.

Setelah kelima tahapan tersebut dilalui, maka sudah terbentuk suatu basisdata untuk aplikasi sistem pakar. Tahapan selanjutnya yang dilakukan adalah melakukan pemrograman antarmuka pengguna dengan sistem (pemrograman view).

Dalam melakukan pemrograman dibagian view, tampilan dikelompokkan sesuai dengan bagiannya masing-masing seperti: tampilan khusus untuk Home (beranda), tampilan ketika pengguna masuk ke sistem sebagai admin, tampilan ketika pengguna masuk ke sistem sebagai pakar dan tampilan 
yang menangani pengguna. Beberapa tampilan dari aplikasi sistem pakar dapat terlihat pada gambar berikut ini.
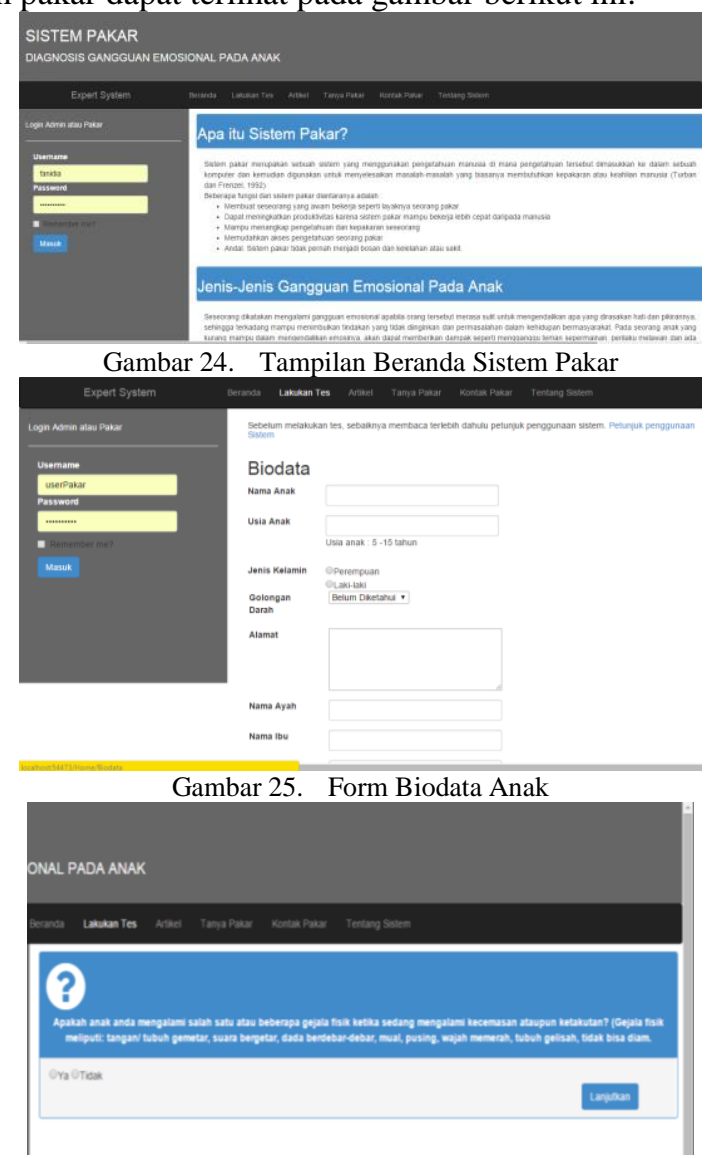

Gambar 26. Proses Menjawab Pertanyaan Sistem

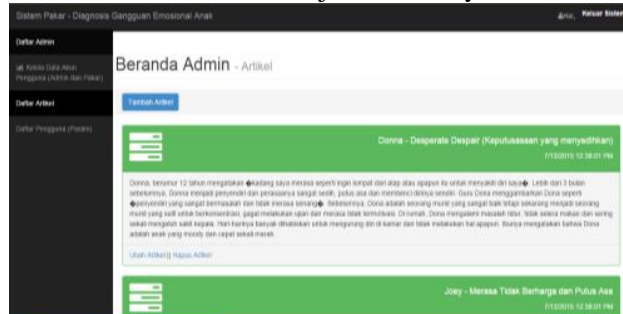

Gambar 27. Tampilan Beranda Admin Menu Artikel

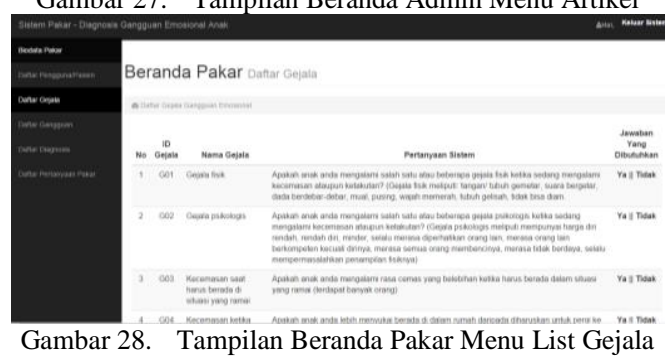

\section{B. Pemrograman Pohon Keputusan}

Dalam melakukan diagnosis gangguan emosional, aplikasi sistem pakar ini menggunakan metode forward chaining berdasarkan dari pohon keputusan yang sebelumnya sudah digambarkan dalam perancangan sebelumnya. Pemrograman pohon keputusan tersebut dilakukan pada suatu class tersendiri yang terpisah, dalam penelitian ini pemrograman pohon keputusan dilakukan pada class yang dinamakan decisionclass.cs dengan menempatkan class tersebut pada folder Helper. Beberapa method yang diberikan pada class decisionclass.cs ditunjukkan pada gambar$$
\{
$$

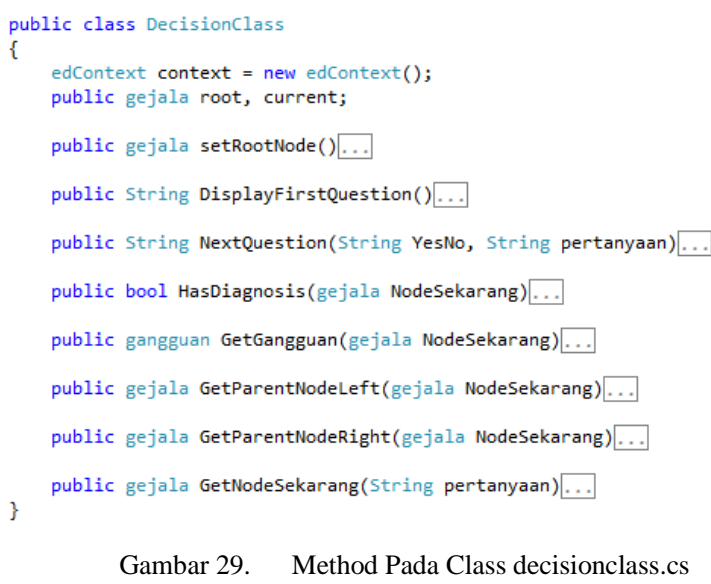

Proses kerja pada method yang terdapat di class decisionclass tersebut akan dijalankan bersamaan dengan method yang berada pada controller Home yang akan dibahas lebih rinci dalam proses pengujian sistem nanti. Penjelasan dari beberapa method yang berada di decisionclass adalah sebagai berikut ini:

- public gejala setRootNode()

Method tersebut berfungsi untuk mengatur node awal yang dijadikan sebagai root, sesuai dengan gambaran pohon keputusan yang sudah dirancang node yang dijadikan root adalah satu objek gejala dengan gejalaID $=$ G01.

- public String DisplayFirstQuestion()

Method tersebut akan mereturn pertanyaan sistem dari node root.

- public gejala GetNodeSekarang(String pertanyaan) Method tersebut akan mendapatkan node yang sekarang dengan menggunakan parameter dari pertanyaan gejala yang sedang ditampilkan untuk pengguna.

- public gejala GetParentNodeLeft (gejala NodeSekarang)

Method tersebut mengecek apakan NodeSekarang merupakan parent dari Node lainnya, jika ya maka akan mengembalikan nilai nodeLeft node tersebut berupa satu objek gejala.

- public gejala GetParentNodeRight(gejala NodeSekarang)

Method tersebut mengecek apakan NodeSekarang merupakan parent dari Node lainnya, jika ya maka akan mengembalikan nilai nodeRight node tersebut berupa satu objek gejala.

- public String NextQuestion(String YesNo, String pertanyaan)

Method tersebut akan mereturn pertanyaan sistem dari node sekarang.

- public bool HasDiagnosis(gejala NodeSekarang) Method tersebut mengecek apakan NodeSekarang mempunyai NodeLeft yang berupa gangguan, jika ya maka 
akan mengembalikan nilai true jika tidak maka akan mengembalikan nilai false.

- public gangguan GetGangguan(gejala NodeSekarang) Method tersebut akan mengembalikan nilai berupa satu objek gangguan apabila node sekarang mempunyai NodeLeft berupa gangguan.

\section{Tahap Pengujian Sistem}

Pengujian aplikasi sistem pakar diagnosis gangguan emosional pada anak menggunakan metode whitebox. Dalam pengujian whitebox setiap fungsi yang ada akan diuji secara rinci jalur-jalur logika yang ada. Metode pengujiannya menggunakan Struktur Kontrol Program untuk memperoleh kasus uji. Pengujian akan dilakukan untuk masing-masing jalur, cabang dan perintah.

Fungsi-fungsi dari aplikasi sistem pakar yang akan dilakukan pengujian sistem diantaranya adalah pada halaman beranda beserta setiap navigasi menu beserta fitur-fitur yang terdapat pada menu tersebut, fungsi login dan logout serta pengujian terhadap metode forward chaining untuk melakukan diagnosis gangguan.

1. Pengujian menu beranda aplikasi sistem pakar. Beranda merupakan halaman awal yang akan ditampilkan ketika mengakses aplikasi sistem pakar. Diagram alir proses pengujian menu beranda adalah sebagai berikut.
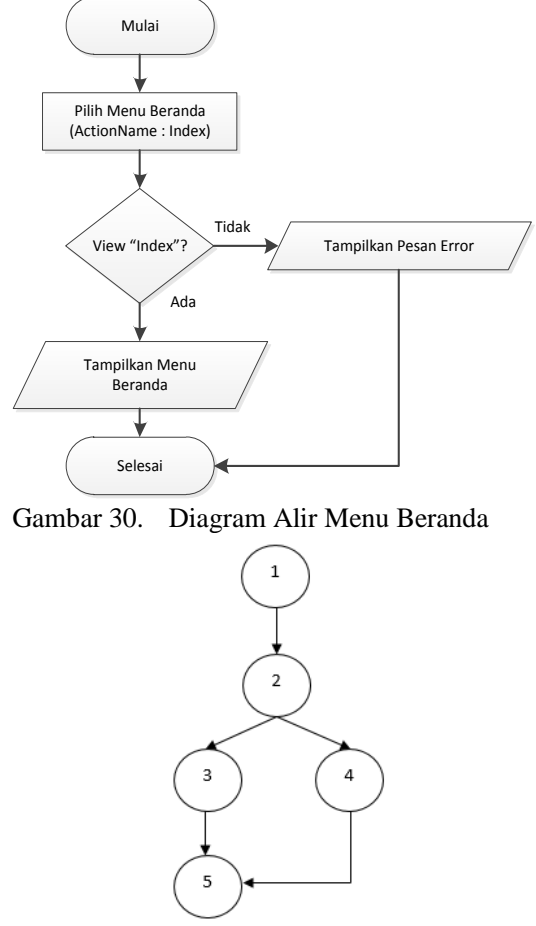

Gambar 31. Flowgraph Menu Beranda

Tabel 12. Jalur Proses Menu Beranda

\begin{tabular}{|c|l|l|l|}
\hline Jalur & \multicolumn{1}{|c|}{ Tahapan } & \multicolumn{1}{|c|}{ Keterangan } \\
\hline 1 & $1-2-3-5$ & Menampilkan Menu Beranda & \\
\hline 2. & $1-2-4-5$ & $\begin{array}{l}\text { View "Index" tidak ada dan } \\
\text { menampilkan pesan kesalahan }\end{array}$ \\
\hline
\end{tabular}

Dari flowgraph pada gambar 31 didapatkan nilai cyclomatic complexity $\mathrm{V}(\mathrm{G})=\mathrm{E}-\mathrm{N}+2$ atau $\mathrm{V}(\mathrm{G})=\mathrm{P}+1$, dimana $\mathrm{E}$ merupakan jumlah Edge, $\mathrm{N}$ merupakan jumlah Node, sedangkan $\mathrm{P}$ merupakan jumlah cabang, sehingga $\mathrm{V}(\mathrm{G})=1+1=2$.

2. Pengujian Lakukan Tes dalam mengisikan biodata pasien. Pada halaman ini, pengguna diminta untuk mengisikan biodata anak sesuai dengan kebutuhan sistem, seperti masukkan untuk nama hanya diizinkan abjad saja tidak dapat diketikkan angka. Sebaliknya untuk umur hanya meminta angka saja, tidak mengizinkan abjad. Pengecekan dapat dilakukan dengan mengetikkan masukkan pada textbox yang disediakan, sedangkan tampilan pesan kesalahan dapat ditampilkan setelah menekan tombol selanjutnya. Diagram alir untuk pengujian navigasi menu Lakukan Tes (mengisi form biodata) ditunjukkan pada gambar 32 berikut.

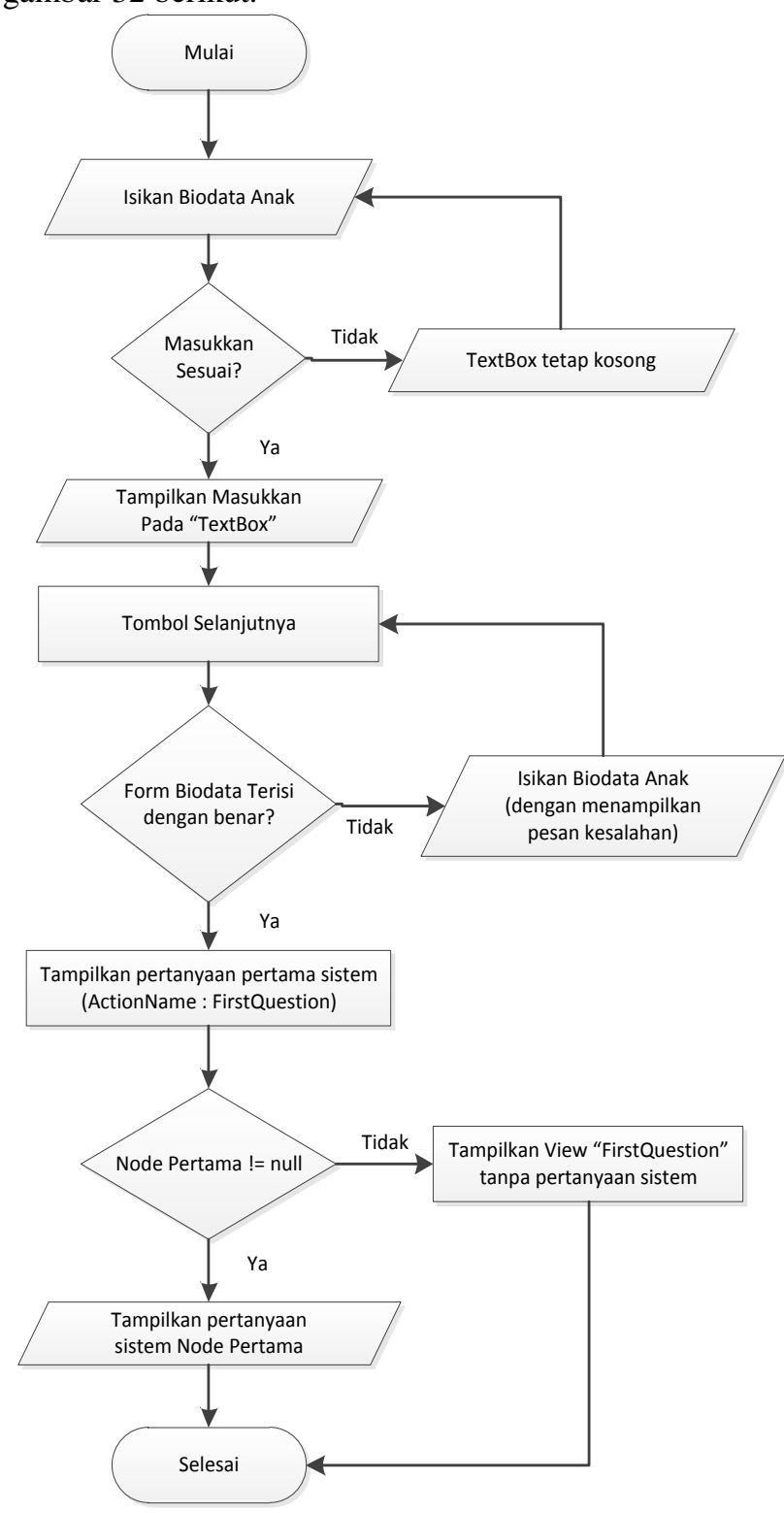

Gambar 32. Diagram Alir Isi Biodata dan Tombol Selanjutnya 


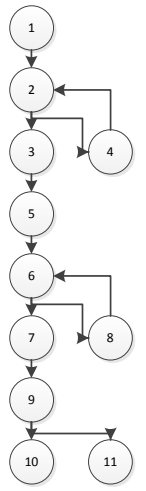

Gambar 33. Flowgraph Isi Biodata dan Tombol Selanjutnya Tabel 13. Jalur Proses Isi Biodata dan Tombol Selanjutnya di Halaman Menu "Lakukan Tes"

\begin{tabular}{|c|c|c|}
\hline Jalur & Tahapan & Keterangan \\
\hline 1. & $\begin{array}{l}1-2-3-5-6-7-9- \\
10\end{array}$ & $\begin{array}{l}\text { Menampilkan pertanyaan sistem node } \\
\text { pertama, data anak yang dimasukkan benar }\end{array}$ \\
\hline 2. & $\begin{array}{l}1-2-3-5-6-7-9- \\
11\end{array}$ & $\begin{array}{l}\text { Masukkan yang diberikan benar tetapi } \\
\text { tidak ada view FirstQuestion }\end{array}$ \\
\hline 3. & 1-2-3-4-1-2-3- & $\begin{array}{l}\text { Pengecekan terhadap kesesuaian input lalu } \\
\text { diproses menampilkan FirstQuestion }\end{array}$ \\
\hline 4. & $\begin{array}{l}1-2-3-4-1-2-3- \\
5-6-8-7-9-11\end{array}$ & $\begin{array}{l}\text { Pengecekan terhadap kesesuaian input lalu } \\
\text { diproses, tidak ada view } \text { FirstQuestion }\end{array}$ \\
\hline
\end{tabular}

Dari flowgraph pada gambar 31 didapatkan nilai cyclomatic complexity $\mathrm{V}(\mathrm{G})=\mathrm{E}-\mathrm{N}+2$ atau $\mathrm{V}(\mathrm{G})=\mathrm{P}+1$, dimana $\mathrm{E}$ merupakan jumlah Edge, $\mathrm{N}$ merupakan jumlah Node, sedangkan $\mathrm{P}$ merupakan jumlah cabang, sehingga $\mathrm{V}(\mathrm{G})=3+1=4$.

3. Pengujian metode forward chaining yang diterapkan pada aplikasi sistem pakar ini. Penerapan metode runut maju terdapat ketika pengguna sistem memberikan jawaban terhadap pertanyaan yang diajukan oleh sistem. Dalam melakukan proses diagnosis, sistem diharapkan dapat melakukan 3 (tiga) kemungkinan hasil diantaranya: anak memiliki gejala yang menunjukkan suatu gangguan emosional, anak memiliki gejala-gejala tetapi belum dapat dikatakan anak tersebut mengalami gangguan emosional karena tidak semua gejala dari suatu gangguan dialami, anak tidak mengalami gejala apapun dan tidak mengalami gangguan emosional. Diagram alir untuk kasus uji forward chaining ditunjukkan pada gambar berikut.

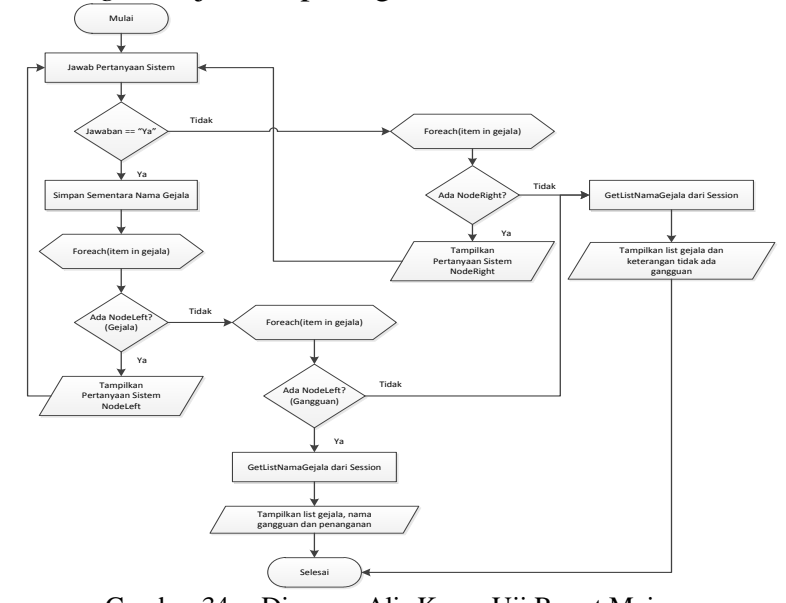

Gambar 34. Diagram Alir Kasus Uji Runut Maju

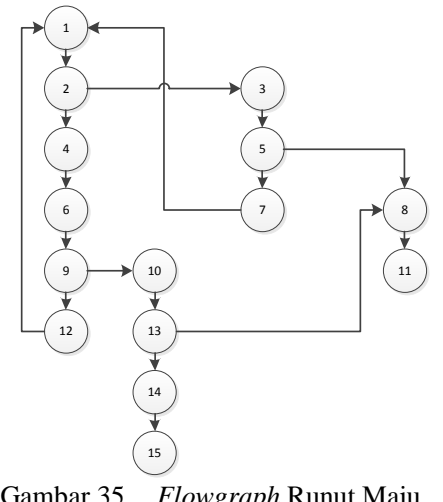

Tabel 14. Jalur Proses Fungsi Runut Maju

\begin{tabular}{|c|l|l|l|}
\hline Jalur & \multicolumn{1}{|c|}{ Tahapan } & \multicolumn{3}{|c|}{ Keterangan } \\
\hline 1. & $1-2-3-5-8-11$ & $\begin{array}{l}\text { Anak tidak mengalami gangguan dan } \\
\text { gejala apapun }\end{array}$ \\
\hline 2. & $\begin{array}{l}1-2-3-5-7-1-2-4-6- \\
9-10-13-8-11\end{array}$ & $\begin{array}{l}\text { Anak mengalami gejala tetapi belum } \\
\text { menunjukkan suatu gannguan }\end{array}$ \\
\hline 3. & $\begin{array}{l}1-2-3-5-7-1-2-4-6- \\
9-10-13-14-15\end{array}$ & $\begin{array}{l}\text { Anak memiliki gejala dan sebuah } \\
\text { gangguan }\end{array}$ \\
\hline 4. & $\begin{array}{l}1-2-4-6-9-10-11-13- \\
14-15\end{array}$ & $\begin{array}{l}\text { Anak memiliki gejala dan sebuah } \\
\text { gangguan }\end{array}$ \\
\hline 5. & $\begin{array}{l}1-2-4-6-9-12-1-2-4- \\
6-9-10-11-13-14-15\end{array}$ & $\begin{array}{l}\text { Anak memiliki gejala dan sebuah } \\
\text { gangguan }\end{array}$ \\
\hline
\end{tabular}

Dari Flowgraph pada Gambar 4.46 didapatkan nilai cyclomatic complexity $\mathrm{V}(\mathrm{G})=\mathrm{E}-\mathrm{N}+2$ atau $\mathrm{V}(\mathrm{G})=\mathrm{P}+1$, dimana $\mathrm{E}$ merupakan jumlah Edge, $\mathrm{N}$ merupakan jumlah Node, sedangkan $\mathrm{P}$ merupakan jumlah cabang, sehingga $V(G)=7+1=8$. Pengujian yang dilakukan untuk mengecek proses runut maju dapat digambarkan pada tabel 4.12 berikut:

Tabel 15. Tabel Skenario Pengujian Dignosis

\begin{tabular}{|c|c|c|c|c|}
\hline No & $\begin{array}{c}\text { Nama } \\
\text { Diagnosis }\end{array}$ & $\begin{array}{l}\text { Runut Jawaban } \\
\text { dari Pengguna }\end{array}$ & $\begin{array}{c}\text { Hasil } \\
\text { Diagnosis } \\
\text { (Setelah } \\
\text { Pengguna } \\
\text { Memberikan } \\
\text { Jawaban) } \\
\end{array}$ & $\begin{array}{l}\text { Hasil } \\
\text { Sesuai }\end{array}$ \\
\hline 1. & $\begin{array}{l}\text { Agorafobia } \\
\text { (A01) }\end{array}$ & $\begin{array}{l}\text { G09 = "Tidak", G02 } \\
=\text { "Ya", G01 = "Ya", } \\
\text { G05 = "Ya", G06 = } \\
\text { "Ya", G04 = "Ya", } \\
\text { G03 = "Ya" }\end{array}$ & $\begin{array}{l}\text { Agorafobia } \\
\text { (A01) }\end{array}$ & Sesuai \\
\hline 2. & $\begin{array}{l}\text { Fobia Sosial } \\
(\mathrm{A} 02)\end{array}$ & $\begin{array}{l}\text { G09 = "Tidak", G02 } \\
=\text { "Ya", G01 = "Ya", } \\
\text { G05 = "Ya", G06 = } \\
\text { "Ya", G04 = } \\
\text { "Tidak", G07 = } \\
\text { "Ya" }\end{array}$ & $\begin{array}{l}\text { Fobia Sosial } \\
\text { (A02) }\end{array}$ & Sesuai \\
\hline 3. & $\begin{array}{l}\text { Fobia Khas } \\
(\mathrm{A} 03)\end{array}$ & $\begin{array}{l}\text { G09="Tidak", G02 } \\
=\text { "Ya", G01 = "Ya", } \\
\text { G05 = "Ya", G06 = } \\
\text { "Ya", G04 = } \\
\text { "Tidak", G07 = } \\
\text { "Tidak", G08 = } \\
\text { "Ya" }\end{array}$ & $\begin{array}{l}\text { Fobia Khas } \\
(\mathrm{A} 03)\end{array}$ & Sesuai \\
\hline 4. & $\begin{array}{l}\text { Gangguan } \\
\text { Panik (A04) }\end{array}$ & $\begin{array}{l}\text { G09= "Tidak", G01 } \\
=\text { "Tidak", G11 = } \\
\text { "Tidak", G10 = } \\
\text { "Ya" }\end{array}$ & $\begin{array}{l}\text { Gangguan } \\
\text { Panik (A04) }\end{array}$ & Sesuai \\
\hline 5. & $\begin{array}{l}\text { Gangguan } \\
\text { Cemas }\end{array}$ & $\begin{array}{l}\text { G09 = "Tidak", G01 } \\
=\text { "Tidak", G11 = }\end{array}$ & $\begin{array}{l}\text { Gangguan } \\
\text { Cemas }\end{array}$ & Sesuai \\
\hline
\end{tabular}




\begin{tabular}{|c|c|c|c|c|}
\hline & $\begin{array}{l}\text { Menyeluruh } \\
\text { (A05) }\end{array}$ & $\begin{array}{l}\text { "Ya", G12 = "Ya", } \\
\text { G13 = "Ya", G14= } \\
\text { "Ya", G15 = "Ya", } \\
\text { G16 = "Ya", G33 = } \\
\text { "Ya", G38 = "Ya" }\end{array}$ & $\begin{array}{l}\text { Menyeluruh } \\
\text { (A05) }\end{array}$ & \\
\hline 6. & $\begin{array}{l}\text { Gangguan } \\
\text { Campuran } \\
\text { Anxietas } \\
\text { dan Depresi } \\
\text { (A06) } \\
\end{array}$ & $\begin{array}{l}\text { G09 = "Tidak", G01 } \\
=\text { "Ya", G02 = "Ya", } \\
\text { G05 = "Tidak", G37 } \\
=\text { "Ya", G39 = "Ya" }\end{array}$ & $\begin{array}{l}\text { Gangguan } \\
\text { Campuran } \\
\text { Anxietas dan } \\
\text { Depresi (A06) }\end{array}$ & Sesuai \\
\hline 7. & $\begin{array}{l}\text { Siklotimia } \\
\text { (A07) }\end{array}$ & $\begin{array}{l}\text { G09 = "Tidak", G01 } \\
=\text { "Tidak", G11 = } \\
\text { "Tidak", G10 = } \\
\text { "Tidak", G40 = } \\
\text { "Ya", G23 = "Ya", } \\
\text { G24 = "Ya", G25 = } \\
\text { "Ya", G26 = "Ya", } \\
\text { G27 = "Ya", G28 = } \\
\text { "Ya", G29 = "Ya", } \\
\text { G30 = "Ya", G31 = } \\
\text { "Tidak", G18 = } \\
\text { "Ya" }\end{array}$ & $\begin{array}{l}\text { Siklotimia } \\
\text { (A07) }\end{array}$ & Sesuai \\
\hline 8. & $\begin{array}{l}\text { Distimia } \\
\text { (A08) }\end{array}$ & $\begin{array}{l}\text { G09 = "Tidak", G01 } \\
=\text { "Tidak", G11 = } \\
\text { "Ya", G12 = } \\
\text { "Tidak", G17 = } \\
\text { "Ya", G19 = "Ya", } \\
\text { G22 = "Ya", G35 = } \\
\text { "Ya" }\end{array}$ & $\begin{array}{l}\text { Distimia } \\
\text { (A08) }\end{array}$ & Sesuai \\
\hline 9. & $\begin{array}{l}\text { Manik } \\
\text { (A09) }\end{array}$ & $\begin{array}{l}\text { G09= "Tidak", G01 } \\
=\text { "Tidak", G11 = } \\
\text { "Tidak", G10 = } \\
\text { "Tidak", G40 = } \\
\text { "Tidak", G20 = } \\
\text { "Ya", G21 = "Ya", } \\
\text { G34 = "Ya", G36 = } \\
\text { "Ya" }\end{array}$ & Manik (A09) & Sesuai \\
\hline 10. & $\begin{array}{l}\text { Depresi } \\
\text { (A10) }\end{array}$ & $\begin{array}{l}\text { G09 = "Tidak", G01 } \\
=\text { "Tidak", G11 = } \\
\text { "Tidak", G10 = } \\
\text { "Tidak", G23 = } \\
\text { "Ya", G24 = "Ya", } \\
\text { G25 = "Ya", G36 = } \\
\text { "Ya", G37 = "Ya", } \\
\text { G38 = "Ya", G39 = } \\
\text { "Ya", G30 = "Ya", } \\
\text { G31 = "Ya", G32 = } \\
\text { "Ya" }\end{array}$ & Depresi (A10) & Sesuai \\
\hline 11. & $\begin{array}{l}\text { Normal } \\
\text { (Tanpa } \\
\text { Gejala) }\end{array}$ & $\begin{array}{l}\text { G09 = "Tidak", G01 } \\
=\text { "Tidak", G11 = } \\
\text { "Tidak", G10 = } \\
\text { "Tidak", G40 = } \\
\text { "Tidak", G20 = } \\
\text { "Tidak" }\end{array}$ & $\begin{array}{l}\text { Normal } \\
\text { (Tanpa } \\
\text { Gejala) }\end{array}$ & Sesuai \\
\hline 12. & $\begin{array}{l}\text { Normal } \\
\text { (Terdapat } \\
\text { Beberapa } \\
\text { Gejala) } \\
\end{array}$ & $\begin{array}{l}\text { G09 = "Tidak", G01 } \\
=\text { "Ya", G02 = } \\
\text { "Tidak" }\end{array}$ & $\begin{array}{l}\text { Normal } \\
\text { (Terdapat } \\
\text { Beberapa } \\
\text { Gejala) } \\
\end{array}$ & Sesuai \\
\hline 13. & $\begin{array}{l}\text { - (Gejala } \\
\text { tidak } \\
\text { dipengaruhi } \\
\text { obat-obatan } \\
\text { tertentu) }\end{array}$ & G09 = "Ya" & - & Sesuai \\
\hline
\end{tabular}

4. Pengujian fungsi login sistem. Pengujian yang dilakukan adalah berupa validitas username dan password serta pengujian apakah sistem sudah dapat membedakan pengguna yang melakukan login adalah seorang pakar atau seorang admin. Selain itu pengujian juga dilakukan untuk menguji apakah menu-menu yang disediakan untuk pakar maupun admin sudah dapat diakses sesuai dengan role yang diberikan. Diagram alir untuk kasus uji tersebut ditunjukkan pada gambar 36 sedangkan flowgraph ditunjukkan pada gambar 37 berikut ini.

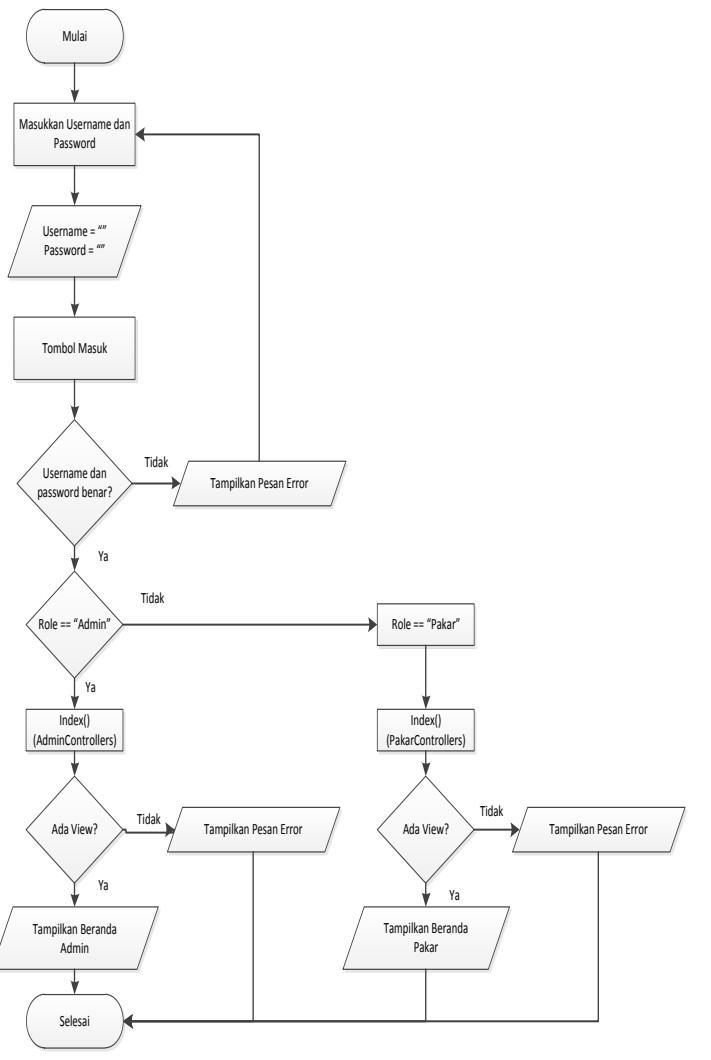

Gambar 36. Diagram Alir Fungsi Login

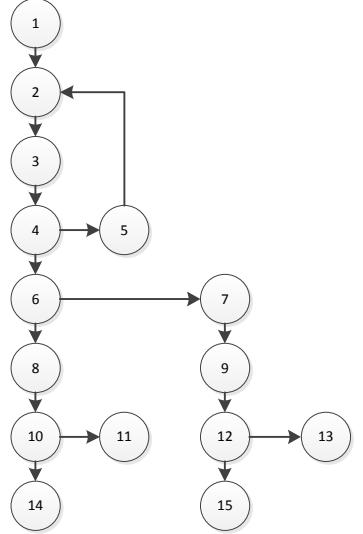

Gambar 37. Flowgraph Fungsi Login

Tabel 16. Jalur Proses Fungsi Login

\begin{tabular}{|c|l|l|}
\hline Jalur & \multicolumn{1}{|c|}{ Tahapan } & \multicolumn{1}{c|}{ Keterangan } \\
\hline 1. & $\begin{array}{c}1-2-3-4-5-2-3-4- \\
6-8-10-14\end{array}$ & $\begin{array}{l}\text { Login sebagai admin dan menampilkan } \\
\text { beranda admin }\end{array}$ \\
\hline
\end{tabular}




\begin{tabular}{|c|l|l|}
\hline 2. & $\begin{array}{l}1-2-3-4-5-2-3-4- \\
6-8-10-11\end{array}$ & $\begin{array}{l}\text { Login sebagai admin tetapi beranda admin } \\
\text { tidak tersedia }\end{array}$ \\
\hline 3. & $\begin{array}{l}1-2-3-4-5-2-3-4- \\
6-7-9-12-15\end{array}$ & $\begin{array}{l}\text { Login sebagai pakar dan menampilkan } \\
\text { beranda admin }\end{array}$ \\
\hline 4. & $\begin{array}{l}1-2-3-4-5-2-3-4- \\
6-7-9-12-15\end{array}$ & $\begin{array}{l}\text { Login sebagai pakar tetapi beranda admin } \\
\text { tidak tersedia }\end{array}$ \\
\hline
\end{tabular}

Dari Flowgraph pada Gambar 37 didapatkan nilai cyclomatic complexity $\mathrm{V}(\mathrm{G})=\mathrm{E}-\mathrm{N}+2$ atau $\mathrm{V}(\mathrm{G})=\mathrm{P}+1$, dimana $\mathrm{E}$ merupakan jumlah Edge, $\mathrm{N}$ merupakan jumlah Node, sedangkan $\mathrm{P}$ merupakan jumlah cabang, sehingga $\mathrm{V}(\mathrm{G})=3+1=4$.

5. Pengujian terakhir adalah bagaimana pengguna (admin atau pakar) yang sudah dapat masuk ke dalam sistem dapat keluar dari sistem dengan memilih menu "Keluar Sistem". Diagram alir untuk kasus uji tersebut ditunjukkan pada gambar 38 sedangkan flowgraph ditunjukkan pada gambar 39 berikut ini.

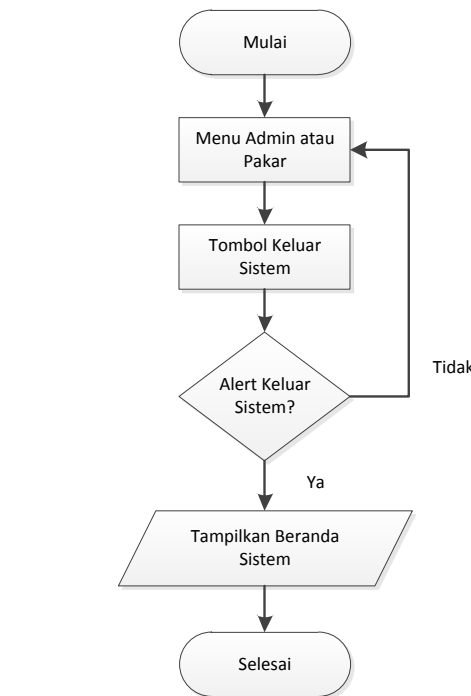

Gambar 38. Diagram Alir Fungsi Keluar Sistem

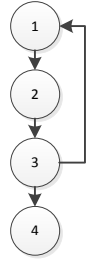

Gambar 39. Flowgraph Keluar Dari Sistem

Tabel 17. Jalur Proses Keluar Sistem

\begin{tabular}{|c|l|l|}
\hline Jalur & \multicolumn{1}{|c|}{ Tahapan } & \multicolumn{1}{c|}{ Keterangan } \\
\hline 1 & $1-2-3-1-2-3-4$ & $\begin{array}{l}\text { Tidak jadi keluar dari sistem, lalu kembali } \\
\text { ke menu awal }\end{array}$ \\
\hline 2. & $1-2-3-4$ & Keluar dari sistem \\
\hline
\end{tabular}

Dari Flowgraph pada Gambar 39 didapatkan nilai cyclomatic complexity $\mathrm{V}(\mathrm{G})=\mathrm{E}-\mathrm{N}+2$ atau $\mathrm{V}(\mathrm{G})=\mathrm{P}+1$, dimana $\mathrm{E}$ merupakan jumlah Edge, $\mathrm{N}$ merupakan jumlah Node, sedangkan $\mathrm{P}$ merupakan jumlah cabang, sehingga $\mathrm{V}(\mathrm{G})=1+1=2$.

Pengujian selanjutnya adalah pengujian sistem untuk pengguna dengan tujuan mengetahui manfaat aplikasi. Proses pengujian dilakukan dengan cara meminta orang tua yang memiliki anak dengan rentang usia 5-15 tahun sebagai responden untuk menjawab 10 soal dengan pilihan jawaban berupa 'Ya' atau 'Tidak'.
Proses pengujian dilakukan dengan cara menjelaskan konsep dari sistem pakar serta mendemokan aplikasi sistem pakar diagnosis gangguan emosional pada anak kepada responden, selanjutnya meminta responden untuk menjawab 10 soal yang tertera pada lembar kuisioner.

Dari hasil jawaban responden yang didapat dari survey selanjutnya akan dimasukkan ke dalam rumus berikut untuk mencari koefisien reprodusibilitas $(\mathrm{Kr})$

$$
K r=1-\frac{e}{n}
$$

sehingga didapat :

$$
\begin{aligned}
& K r=1-\frac{26}{100} \\
& K r=0.74
\end{aligned}
$$

Setelah $\mathrm{Kr}$ diketahui, langkah selanjutnya ialah menghitung koefisien skalabilitas (Ks) dengan menggunakan rumus berikut :

$$
K s=1-\frac{e}{x}
$$

sehingga didapat :

$$
\begin{aligned}
& K s=1-\frac{26}{0,5(100-26)} \\
& K s=|1-2| \\
& K s=1
\end{aligned}
$$

Karena Ks memiliki nilai >0,60 maka disimpulkan variabel yang ada baik untuk digunakan dalam survei dan hasil uji yang didapat berkaitan dengan penelitian ini adalah responden menunjukkan respon yang bagus pada aplikasi ini beserta konsep yang terdapat di dalamnya.

Aplikasi ini juga telah diuji dan diperiksa kebenaran data yang terdapat didalamnya dan dinyatakan data benar, tetapi masih terlalu dini untuk dapat diimplementasikan secara langsung oleh beberapa orang psikolog diantaranya Maharani, M.Psi dan Nuning Suhardiningsih, M.Psi. Selain oleh para psikolog, aplikasi juga diuji oleh konsultan kesehatan jiwa yaitu Witcha Rea A, S.Psi dan Margareta Dwina K, S.Psi. Keterangan wawancara dan hasil pengujian terlampir di dalam laporan ini.

\section{KESIMPULAN}

Kesimpulan dari penelitian tugas akhir ini adalah sebagai berikut:

1. Aplikasi sistem pakar diagnosis gangguan emosional pada anak merupakan sebuah aplikasi berbasis website yang memiliki fitur inti dapat melakukan diagnosis gangguan emosional melalui gejala yang diberikan sistem dalam bentuk pertanyaan kepada pengguna.

2. Metode yang dilakukan pada sistem pakar ini adalah dengan forward chaining (runut maju) dengan menggunakan model representasi kaidah produksi. Dalam menggunakan model tersebut, informasi yang diperoleh dari pakar diterjemahkan ke dalam tabel keputusan dan selanjutnya dibuat suatu pohon keputusan.

3. Pengujian yang dilakukan pada aplikasi ini adalah menggunakan metode whitebox dan memperoleh hasil 
cycolomatic complexity yang diperoleh sudah sesuai dengan tabel jalur proses yang dibuat, sehingga dapat disimpulkan bahwa logika yang diberikan untuk sistem sudah sesuai dengan kebutuhan sistem.

4. Pengujian sistem dengan tujuan validitas data dilakukan oleh empat orang pakar dibidang kesehatan jiwa, memberikan kesimpulan bahwa gejala yang mengarah ke dalam suatu gangguan emosional sudah sesuai, tetapi masih terlalu dini jika aplikasi diimplementasikan secara langsung dan dipergunakan, karena batasan gangguan masih mempunyai cakupan yang terlalu luas.

5. Pengujian sistem dengan tujuan mengetahui manfaat aplikasi dilakukan oleh sepuluh orang pengguna (responden) memberikan hasil nilai $\mathrm{Kr}>0.8$ dan nilai $\mathrm{Ks}>$ 0.6 yang artinya responden menunjukkan respon yang bagus pada aplikasi ini beserta konsep yang terdapat di dalamnya.

\section{SARAN}

Saran yang diberikan dalam upaya pengembangan sistem yang lebih baik dikemudian hari diantaranya:

1. Sistem pakar diagnosis gangguan emosional anak ditujukan untuk anak normal (tanpa ada perhitungan faktor lain, seperti keterbelakangan mental), sehingga memungkinkan untuk pengembangan aplikasi selanjutnya dapat memperhitungkan faktor-faktor lain yang mungkin mempengaruhi seperti latar belakang lingkungan sosial maupun keluarga.

2. Penambahan fitur rekap data (termasuk cetak rekap data) yang dapat diurutkan berdasarkan waktu dari hasil pengguna yang sudah melakukan tes pada sistem pakar.

\section{DAFTAR PUSTAKA}

[1.] F. F. Rohman and A. Fauzijah, "Rancang Bangun Aplikasi Sistem Pakar Untuk Menentukan Jenis Gangguan Perkembangan Pada Anak," Media Informatika, vol. 6, pp. 1-23, 2008.

[2.] E. Rich, K. Knight and S. B. Nair, Artificial Intelligence Third Edition, The McGraw-Hill Companies, 2009

[3.] R. Hidayat dan S. Minarni, "Rancang Bangun Aplikasi Sistem Pakar untuk Kerusakan Komputer dengan Metode Backward Chaining," Jurnal TEKNOIF, pp. 26-35, 2013.

[4.] T. Sutojo and dkk, Kecerdasan Buatan, Yogyakarta: Andi Publishing, 2011.

[5.] S. Hartati and S. Iswanti, Sistem Pakar dan Pengembangannya, Yogyakarta: Graha Ilmu, 2008.

[6.] wikipedia, "wikipedia," [Online]. Available: http://id.wikipedia.org/wiki/Microsoft_Visual_Studio. [Accessed 12 March 2015].

[7.] D. Esposito, Programming Microsoft ASP.NET 4, USA: Microsoft, 2011.

[8.] P. Jeffrey and dkk, ASP.NET MVC 4 IN ACTION, Shelter Island.

[9.] M. Zainul, "Thinking Original Entity Framework," 1 July 2011. [Online]. Available: https://zainulmasadi.wordpress.com/2011/07/01/entityframework. [Accessed 12 march 2015].

[10.] Nagel, Christian, dkk. Professional C\#4 and .NET 4, Canada: Wiley Publishin, Inc. 2010.

[11.] A. Nugroho, Algoritma dan struktur data dengan C\#, Yogyakarta: ANDI, 2009.

[12.] A. Troelsen, Pro C\# 2008 and the .NET 3.5 Platform (4th Edition), New York: Springer-Verlag New York, Inc., 2007.

[13.] Aiskahendra, "Perbedaan Razor dan aspx," 17 December 2010. [Online]. Available: https://aiskahendra.wordpress.com/2010/12/17/asp-netmvc-3-mengenal-syntax-razor. [Accessed 12 March 2015].

[14.] kuliahso, "Lapisan Perangkat Lunak," 13 March 2012. [Online]. Available: https://kuliahso.wordress.com/2012/03/13/softwarelayer-lapisan-perangkat-lunak. [Accessed 12 March 2015]

[15.] E. J. Mash and D. A. Wolfe, Abnormal Child Psychology, Fourth Edition, USA: Wadsworth Cengange Learning, 2010.

[16.] Maslim, Rusdi. Buku Saku Diagnosis Gangguan Jiwa Rujukan Ringkas dari PPDGJ-III

[17.] Pedoman Penggolongan Diagnosis Gangguan Jiwa di Indonesia, III, PPDGJ III, Departemen Kesehatan RI, Direktorat Jendral Pelayanan Medik, 1993. 